\title{
Compensating Wage Differentials and Voluntary Job Changes: Evidence from West Germany*
}

\author{
Ernesto Villanueva ${ }^{\dagger}$
}

January 29, 2004

\begin{abstract}
Does the labor market place wage premia on jobs that involve physical strain, job insecurity or bad regulation of hours? This paper derives bounds on the monetary returns to these job disamenities in the West German labor market. We show that in a market with dispersion in both job characteristics and wages, the average wage change of workers who switch jobs voluntarily and opt for consuming more (less) disamenities, provides an upper (lower) bound on the market return to the disamenity. Using longitudinal information from workers in the German Socio Economic Panel, we estimate an upper bound of $5 \%$ and a lower bound of $3.5 \%$ for the market return to work strain in a job.
\end{abstract}

Keywords: Wage Level and Structure, Job Satisfaction, Compensation Packages.

JEL: J28, J31, J33

${ }^{*}$ I thank Rita Almeida, Dörte Domeland, Maia Guell, Sergi Jimenez, Dan Hamermesh, Adriana Kugler, Francis Kramarz, Steven Pischke, Coen Teulings, Jan Van Ours and participants at the 5th Conference of GSOEP users and Universitat Pompeu Fabra Labor seminar for comments and suggestions. This work owes much to the encouragement of Joe Altonji. Carlos Gonzalez and Tobias Pfütze provided outstanding research assistance. Funding by the Spanish Ministry of Science and Industry through grant SEC2001-0674 is gratefully acknowledged. All errors are mine.

${ }^{\dagger}$ Department of Economics, Universitat Pompeu Fabra. Ramon Trias Fargas 25-27 08005 Barcelona, SPAIN. Email: ernesto.villanueva@upf.edu 


\section{Introduction}

Do labor markets place wage premia on jobs that involve disamenities like physical effort, job insecurity or bad hours regulation? The answer to that question is a key to understanding the effectiveness of public policies aimed to improve nonmonetary conditions on jobs. For example, the theory of compensating wage differentials predicts that a public intervention to limit the consumption of disamenities on the job may lower the welfare of workers who choose to consume disamenities in exchange for high wages. Conversely, the same policy may be effective in a segmented labor market, in which equally productive workers are placed either in bad jobs (with bad nonmonetary characteristics and low wages) or good jobs (the opposite). From a different perspective, the existence of wage premia to disamenities is crucial to assess the extent of wage discrimination between two groups of workers, if amenities are differentially present on the jobs held by these groups. This paper implements a new econometric strategy that bounds the wage return to the presence of heavy work load on a job, bad hours regulation and job insecurity. ${ }^{1}$

The theoretical foundation for the existence of market return to disamenities comes from the theory of compensating wage differentials (Rosen, 1986). That theory predicts that workers sort into jobs according to their preferences and the technological possibilities of firms, so that workers with higher tolerance towards amenities work in firms with higher cost of provision of amenities. A substantial literature has estimated hedonic wage regression models to infer whether or not labor markets place premia on jobs that involve physical effort or job insecurity, obtaining mixed results. ${ }^{2}$ Hedonic wage regressions are often criticized for not accounting for measurement error in measuring worker's productivity, an omission that biases the estimates against finding evidence for compensating wage differentials. ${ }^{3}$ Other literature has examined whether or not longitudinal changes in job characteristics following

\footnotetext{
${ }^{1}$ The main focus of this work is to recover the market locus between wages and amenities, not to recover the underlying worker's preference parameters and firm cost functions. Ekeland, Heckman and Nesheim (2003) discuss under which conditions these deep structural parameters can be identified, but they take as given the market locus between wages and nonmonetary disamenities

${ }^{2}$ See Lucas (1977) for an early application of this procedure in the US. In France, Daniel and Sofer (1998) find mixed evidence for compensating differentials associated to environmental conditions on the job, like noise, physical effort, or exposure to vibration. Namely, they find evidence that in strongly unionized industries there is a positive relationship between wages and disamenities of bargaining over wages. For the German case, Lorenz and Wagner (1989) find that job requirements of physical effort affect wages negatively, contrary to the predictions of the theory.

${ }^{3}$ See Hwang et al (1992) for a discussion on the consequences of mismeasuring worker's productivity. Hwang, Reed et al. (1998) discuss other biases associated to the estimation of hedonic models.
} 
job changes are associated to wage changes. ${ }^{4}$ Nevertheless, the self-selection of job changers may bias the estimates of individual fixed-effects models (Solon, 1988). Perhaps because of that evidence, several authors have modified the implicit markets approach, to analyze models in which workers care about nonmonetary job characteristics, but in which labor market imperfections generate a negative relationship between wages and disamenities - see Hwang, Mortensen and Reed (1998), Lang and Majumdar (forthcoming) or Sofer and Daniel (1998). Consistent with that approach, Gronberg and Reed (1994) focus on a different parameter: the worker's marginal willingness to pay for the absence of physical effort or other environmental disamenities on their jobs. Instead of using hedonic regression methods, Gronberg and Reed estimate the effect of the presence of disamenities on the duration of the job, using US data. ${ }^{5}$

This paper implements a new strategy to estimate market monetary returns to the presence of work strain on a job, to the risk of losing the job and to bad regulation of hours in Germany. ${ }^{6}$ We assume that the labor market is characterized by the presence of search frictions, so that there is dispersion in job characteristics and in wages, like in Hwang, Mortensen and Reed (1998). We first show that in a market that places wage premia on the presence of disamenities on jobs, the average wage change of the workers who switch jobs voluntarily and opt for consuming more disamenities, provides an upper bound on the market return to the disamenity. The reason is that the distribution of observed wage changes is censored from below, as offers that do not give a sufficiently high wage increase are rejected by potential quitters. Under conditions spelled below, the average wage change following voluntary switches to jobs with less disamenities provides a lower bound on the market return to the presence of a disamenity. We also show that, in a labor market that places a wage penalty on jobs with disamenities, if a worker changes voluntarily to a job with better nonmonetary characteristics, his or her average wage must increase. Hence, our empirical strategy identifies whether or not the labor market places wage premia on disamenities consumed on the job. $^{7}$

\footnotetext{
${ }^{4}$ In the US, Brown (1981) finds no systematic effect of characteristics of jobs that are likely to enter the utility function of the worker on wages, once unobservable ability is controlled for. In Sweden, Duncan and Holmlund (1983) also find mixed evidence for the effect of environmental conditions on wages.

${ }^{5}$ Gronberg and Reed obtain that workers are willing to pay for the absence of risky conditions and for the absence of characteristics related to physical effort on the current job.

${ }^{6}$ We document that a worse work strain is more likely to be reported if workers move to jobs that require exerting partially or frequently physical effort and working longer hours. Similarly, a bad regulation of hours is more likely to be reported if the job requires more often overtime work.

${ }^{7}$ Altonji and Paxson (1988) use a similar methodology to assess whether or not jobs in the US economy
} 
We test our empirical strategy using a sample of male job changers from the German Socioeconomic Panel (GSOEP). The German case is specially interesting for two reasons. The first is that Germany did not experience the increase in wage dispersion that affected the US and UK during the 80s (Abraham and Houseman, 1995). An increase in wage inequality can cause a changing relationship between wages and disamenities through income effects (see Hamermesh (1999) and Weiss (1976)). Second, the GSOEP is an unusually rich dataset, containing longitudinal information on the variables needed for the analysis: motives for job-to-job changes, wages in each job, nonmonetary characteristics of jobs, and individual satisfaction with the job.

Our strategy proceeds in three steps. First, using a subsample of the GSOEP job changers, we document that the increases in work load reports are correlated with increases in physical effort requirements and with increases in hours of work. We also document that reports of a bad regulation of hours are correlated with more frequent overtime work. Second, we test whether or not the job attributes considered enter into the utility of the worker. This is done by regressing the (individual) change in job satisfaction following a quit, on the change in several job characteristics. We find that changes to jobs with a worse work load, worse regulation of hours, higher probability of losing the job, higher mismatch between the skills required on the job and the knowledge of the worker, and lower earnings decrease reported job satisfaction. Finally, we regress the change in the logarithm of the wage after a quit on separate binary variables indicating if the consumption of the disamenity increased or decreased after the change. We show that the coefficient of the binary variable indicating an increase (decrease) in the consumption of the disamenity provides an upper (lower) bound for the monetary returns to the presence of that disamenity.

The paper has three main findings. First, the hypothesis that the labor market places wage penalties on jobs with disamenities is generally not supported by the data. Second, we find evidence of trade-offs between wages and three disamenities: heavy work load, mismatch between worker talents and skills required by the job and, more tentatively, bad regulation

are tied packages of hours and wages. Nevertheless, they do not focus on equilibrium market relationships, but on the estimation of parameters of the utility function, such as the compensated elasticity of the hours of work to an increase in the wage. Usui (2003) also exploits wage changes between male and female dominated jobs to ascertain whether or not jobs with higher proportion of males carry a wage premium, controlling for possible (unobserved) disamenities. Her identification strategy differs from ours in two aspects. First, Usui (2003) relies on the comparison of voluntary and involuntary job changers, that we do not exploit. Second, our empirical strategy relies on the asymetry of wage changes between changes to jobs involving higher consumption of disamenities and to jobs involving lower consumption of disamenities. Usui (2003) does not exploit such asymetry. 
of hours. These results are surprising, given that the German labor market is commonly regarded as very rigid. We estimate an upper bound of $5 \%$ for the market return to working in a job with a heavy work load, and a lower bound of 3.5\%. The upper bound on the monetary return on working in jobs that involve a set of skills that workers do not typically have is $6 \%$, and the lower bound is zero. The evidence for a wage premia to bad hours regulation is mixed. The lower bound on the presence of bad regulation of hours is not significantly different from zero in most specifications. The estimate of the upper bound is about $4.5 \%$ but in some specifications, the estimate is not significantly different from zero. Finally, we do not find systematic evidence of trade-offs between job insecurity and wages.

These results are robust to the inclusion of other job characteristics, like industry controls, fringe benefits, commuting time and possibilities of advancement on the job. To ensure that the strategy used in the paper is not picking up the effect of promotions, we also examine the relationship between wages and disamenities in a sample of job movers within the same firm, assuming that such job changes are mainly promotions. We find that the relationship between wages and disamenities is statistically different for quitters and for individuals who change jobs within the same firm. Finally, the identification strategy proposed in this paper depends crucially on the job change being voluntary, as opposed to a lay-off, for example. We discuss that these two types of moves are observationally different in the GSOEP.

The paper is structured as follows. Section 2 discusses how the observed evolution of wages and disamenities after a voluntary job change can be used to infer the presence of market returns to a disamenity. Section 3 describes the dataset used and the empirical strategy. Section 4 discusses the measures of job disamenities, and assesses whether or not they enter into the utility of the worker. Section 5 presents wage regressions on the change of disamenities among quitters. Section 6 concludes.

\section{Wage dispersion and disamenities}

This section follows Rosen (1986) and Usui (2003). Consider a job market with search frictions and in which workers do not observe all available positions. Each job is characterized by a wage level $w$ and by a level of nonpecuniary disamenities $D$. Jobs in which $D$ equals 1 are associated with some disamenity (we term these "dirty" jobs), whereas, $D$ takes value 0 if the disamenities is not present in the position ("clean" jobs). With an exogenous probability of arrival, each worker receives a job offer $(w, D)$, as in Hwang, Mortensen and Reed (1998). 
The preferences of a worker are represented as follows

$$
u(w, D)=w-Z D
$$

$Z$ is the (worker-specific) marginal willingness to pay to avoid the consumption of a disamenity. Higher values of $Z$ denote lower tolerance for disamenities. ${ }^{8}$

Assumption 1: The offers received by each worker are independent of his or her marginal willingness to avoid the disamenity.

The rationale behind this assumption is that $Z$ is not observable to firms, that cannot target their offers to a specific kind of worker. Hwang, Mortensen and Reed (1998) show that in a labor market with search frictions, a constant arrival rate of offers and heterogeneity in the cost of provision of amenities by firms, there is an equilibrium distribution of wages and disamenities in the market. We augment the equilibrium wage distribution in their paper by including an individual-specific component $\mu$, related to the unobserved ability of the worker so that the wage of a worker is given by the following expression

$$
w=\delta D+\mu+\varepsilon
$$

$\delta$ denotes the market monetary return to the presence of a disamenity. $\varepsilon$ denotes the match-specific productivity, in excess of the average wage of workers with the same unobserved ability and same job conditions. By definition, $E(\varepsilon \mid D, \mu)=0$. Further, assumption 1 implies that $E(\Delta \varepsilon \mid Z)=0 .{ }^{9}$ Given that we focus on binary indicators of the presence of disamenities, nothing is lost by assuming that (1) is linear. Hwang et al. (1998) and Lang and

\footnotetext{
${ }^{8}$ Note that a linear specification in $C$ and $D$ is not generally restrictive, as one can always define any utility function defined over consumption and disamenities $u(C, D)$ (where $D$ can take values 0 and $1, \frac{\partial u(C, D)}{\partial C}>0$ and $u(C, 1)<u(C, 0)$ for a given $C$ ). If we denote $C_{0}$ as the wage level in a position without disamenities, $Z$ can be defined as the consumption required to accept a job that involves consuming disamenities:

$$
u\left(C_{0}, 0\right)=u\left(C_{0}+Z, 1\right)
$$

${ }^{9} E(\Delta \varepsilon \mid Z)=0$ implies that the random arrival of job offers to a worker does not depend on the level of tolerance of the worker. That condition would not hold in a model in which workers with higher tolerance were easily identifiable, and the arrival rate of offers were endogenous and differed across worker groups. In such a case, an equilibrium could exist in which those workers receive offers better than random $E(\Delta \varepsilon \mid Z)>0$. In our empirical implementation, we proxy $Z$ by the reported satisfaction in the present job.
} 
Majumdar (forthcoming) show that, even if all workers dislike the presence of a disamenity on the job, search frictions can cause $\delta$ to be either a positive or negative number. ${ }^{10}$

Direct estimation of (1) is likely to yield biased estimates of $\delta$, because of well-known omitted variable in the case of OLS (see Daniel and Sofer (1998), and the references therein) or because of selection bias of quitters in the case of individual fixed effects models (Solon, 1988). Another possibility is to include a selection term, but it is not always straightforward to find variables that affect the consumption of disamenities $D$, but are uncorrelated with wages. ${ }^{11}$ We adopt a different strategy, exploiting the revealed preference about wages and disamenities when workers change jobs voluntarily. A worker who changes voluntarily $(Q=1)$ attains a higher level of utility after the change so that

$$
u\left(w_{1}, D_{1}\right)=w_{1}-Z D_{1}>w_{0}-Z D_{0}=u\left(w_{0}, D_{0}\right)
$$

Where a subscript 1 denotes the new job and 0 denotes the old job. We define the following moment that, provided we have a proxy for $Z$, is observable in the data

$$
E\left(\Delta w \mid Q=1, D_{1}, D_{0}, Z\right)=d_{0}+d_{1} 1\left(D_{1}>D_{0}\right)+d_{2} 1\left(D_{1}<D_{0}\right)
$$

$1\left(D_{1}>D_{0}\right)$ (resp. $\left.1\left(D_{1}<D_{0}\right)\right)$ is an indicator function that takes value one if the level of disamenities increased (decreased) after the job change and zero otherwise. Next, we discuss how a sample of voluntary job changers allows us to relate $d_{1}$ and $d_{2}$ to the parameter of interest $\delta$.

\subsection{Case 1: Labor markets reward the presence of a disamenity $(\delta>0)$}

Assume that $\delta$ is positive. Consider a worker who currently has a "clean" job $\left(D_{0}=0\right)$. That worker only accepts a "dirty" job if the wage difference is enough to compensate the

\footnotetext{
${ }^{10}$ Hwang, et al. (1998) show that $\delta$ could be negative if the arrival offer rate is high enough relative to the (exogenous) job destruction rate. Using a model of nonsequential search, Lang and Majumdar (2003) also show that a market with search frictions has an equilibrium solution. In the case in which workers are heterogenous in $Z$, they show that the market relationship between $w$ and $D$ can be either positive or negative.

${ }^{11}$ See Olson (2002), for an application for the US regarding the monetary payoff for the absence of employerprovided health insurance.
} 
worker for the worsened working conditions. In other words, voluntary changes from "clean" to "dirty" jobs are only observed if

$$
\Delta w=w_{1}-w_{0}=\delta\left(D_{1}-D_{0}\right)+\varepsilon_{1}-\varepsilon_{0} \geq Z\left(D_{1}-D_{0}\right)
$$

where we have ignored mobility costs for the sake of simplicity. Hence, the observed average wage change following a (voluntary) job change from "clean" jobs to "dirty" ones is:

$$
d_{1}=\delta+E_{\Delta \varepsilon}(\Delta \varepsilon \mid \delta+\Delta \varepsilon \geq Z, Z)=\delta+E_{\Delta \varepsilon}(\Delta \varepsilon \mid \Delta \varepsilon \geq Z-\delta, Z)
$$

$d_{1}$ can be decomposed in two components: the market return to the presence of a disamenity $\delta$, and a selection component $E(\Delta \varepsilon \mid \Delta \varepsilon \geq Z-\delta, Z)$. The latter component appears in (2.1) because the selected sample of voluntary changers only includes wage increases that exceed the worker's monetary valuation of consuming disamenities. Given assumption 1, the second term in the right hand-side of (2.1) is a positive number. ${ }^{12}$

Similarly, assume that a worker is currently working in a position that involves consuming disamenities $\left(D_{0}=1\right)$. This worker changes to a "clean" job in which $D=0$ only if the wage decrease associated to the change is smaller than the utility gain from decreasing the consumption of disamenities, or $\Delta w>-Z$. Hence, the average wage change following a voluntary change from a "dirty" job to a "clean" one is

$$
\begin{aligned}
d_{2} & =-\delta+E_{\Delta \varepsilon}(\Delta \varepsilon \mid-\delta+\Delta \varepsilon>-Z, Z)= \\
& =-\delta+E_{\Delta \varepsilon}(\Delta \varepsilon \mid \Delta \varepsilon>-Z+\delta, Z)
\end{aligned}
$$

By the same reasoning above, the selection term in the right-hand-side of (2.2) is positive. The sign of (2.2) is, in principle, undetermined, given that it is the sum of a negative and a positive component. But we can obtain two restrictions, summarized in the following proposition.

Proposition 1: If the market rewards on average the presence of a disamenity on the job $(\delta>0)$, (i) $d_{1}$, the average wage change following a voluntary job change that increases the

\footnotetext{
${ }^{12}$ The reason is that $E(\Delta \varepsilon \mid \Delta \varepsilon \geq Z-\delta, Z) \geq E(\Delta \varepsilon \mid \Delta \varepsilon \geq-\infty, Z)$

$=E(\Delta \varepsilon \mid Z)=0$. The first inequality arises by the definition of a censored random variable. The second equality holds by assumption.
} 
consumption of amenities, is positive and greater than the market return $\delta$ (ii) $d_{2}$ is smaller in absolute value than $d_{1}$ (iii) If $d_{2} \leq 0$, then $\left|d_{2}\right|<\delta<\left|d_{1}\right|$

The proof is derived in Appendix 1.

\subsection{Case 2: Labor markets penalize the presence of a disamenity $(\delta \leq 0)$}

Hwang, Mortensen and Reed (1998) show that an equilibrium locus in which $\delta \leq 0$ can arise when the arrival of offers is very high, relative to the job destruction rate. Lang and Majumdar (forthcoming) provide a similar result. ${ }^{13}$ For the sake of simplicity, we assume that $\delta$ is zero, and examine the relationship between wage changes and the consumption of disamenities on the job that such job market generates. Using the same reasoning as in the previous subsection, the following moment can be defined.

$$
\begin{aligned}
E(\Delta w \mid Q & \left.=1, D_{1}, D_{0}\right)=d_{0}+d_{1} 1\left(D_{1}>D_{0}\right)+d_{2} 1\left(D_{1}<D_{0}\right)= \\
d_{0}+E_{\Delta \varepsilon}(\Delta \varepsilon \mid \Delta \varepsilon & >Z, Z) 1\left(D_{1}>D_{0}\right)+E_{\Delta \varepsilon}(\Delta \varepsilon \mid \Delta \varepsilon \geq-Z, Z) 1\left(D_{1}<D_{0}\right)
\end{aligned}
$$

Note that, as in the previous subsection, $d_{1}$ cannot be lower than $d_{2} \cdot{ }^{14}$ The following proposition can be easily derived.

Proposition 2: If there is not average market return to the presence of a disamenity $(\delta=0)$, (i) The average wage increase following a voluntary increase in the consumption of amenities, $d_{1}$ is positive (ii) $d_{2}$ is positive and smaller in absolute value than $d_{1}$

Voluntary job changes in a segmented labor market are observably different from the former case, as $d_{2}$ must be greater than zero. The intuition is the following. Voluntary job changes to jobs with better characteristics imply no relative wage increases, as the market does not reward the presence of the disamenity. Nevertheless, some potential quitters will refuse changes that do not entail a sufficiently high wage increase (in other words, $E_{\Delta \varepsilon}(\Delta \varepsilon \mid \Delta \varepsilon \geq-Z, Z)$ is positive.) Overall, the relative wage change following a change to a job with less disamenities must be positive. By the same reasoning, $d_{2}$ is also positive if $\delta$ is

\footnotetext{
${ }^{13}$ Nevertheless, in a model like Hwang et al's (1998), when the market equilibrium is such that $\delta$ is negative, one could not observe voluntary job changes from "clean" to "dirty" jobs, as the overall utility is higher in the former. In a different setting, Sofer and Daniel (1998) prove that differential bargaining across sectors may create a positive relationship between amenities and wages, evidence consistent with a segmented labor market.

${ }^{14}$ The reason is that, provided that $Z$ is positive. $E_{\Delta \varepsilon}(\Delta \varepsilon \mid \Delta \varepsilon>Z, Z) \geq E_{\Delta \varepsilon}(\Delta \varepsilon \mid \Delta \varepsilon>-Z, Z)$,
} 
strictly negative. ${ }^{15}$

\subsection{Testable implications}

- In a labor market that penalizes the presence of a disamenity on the job, voluntary job changes from "dirty" to "clean" jobs involve positive wage changes.

- If the market places wage premia on the presence of disamenities in a job, average wage changes following voluntary changes from "clean" to "dirty" jobs should exceed average wage changes following voluntary job changes from "dirty" to "clean" jobs.

- If the market places wage premia on the presence of disamenities, and $d_{2} \leq 0$, the (average) market return to the presence of a disamenity is bounded above by (2.1) and below by (2.2).

\section{The data and the empirical specification}

The sample is drawn from the 1984-2001 waves of the German Socio-Economic Panel (GSOEP). The GSOEP started in 1984, interviewing 5,921 households. Since then, it follows the members of the panel. The GSOEP has three features that makes the survey specially suitable to implement the methodology in the previous section. First, the GSOEP has yearly information on wages and, for some years, respondents are asked about several characteristics of their jobs. Second, workers are asked if they have changed their job in the last year, and if so, what was the reason of the change. That feature allows us to identify voluntary job changes. Finally, and most important, an unusual aspect of this survey is that workers are asked to explicitly compare several characteristics of their new job to the characteristics of their last one. This aspect has two advantages. First, it is common to impute disamenities to jobs based on out-of sample surveys on characteristics of occupation or industry, such as the Dictionary of Occupational Titles in the US. The accuracy of the imputation depends on the quality of the report of occupational and industry codes, which is not always reliable (Mellow and Sider, 1983). The problem gets worse when one exploits longitudinal data, as the bias due to measurement error is exacerbated. Second, the information in the GSOEP allows for more detailed variation in the change of characteristics than changes in industry

\footnotetext{
${ }^{15}$ If $\delta<0,\left|d_{1}\right|$ is not necessarily bigger in absolute value than $\left|d_{2}\right|$
} 
or occupation. ${ }^{16}$ The exact wording of the question is:

"How do you view your current position compared to your previous one? In which of the following points has your new job improved or worsened your status? Or has it stayed about the same?

(a) the type of work?

(b) salary, wages?

(c) work load?

(d) commuting?

(e) work hours regulation?

(f) benefits?

(g) job security?

In addition, the GSOEP asks job changers:

"Can you use your knowledge and skills more, the same or less than in your last job?"

Given that it is difficult to establish a priori what of the aforementioned characteristics enter into the utility of a worker, Section 4 examines if those characteristics are related to the reported satisfaction of the worker. From the empirical results, we focus the analysis on work load (related to the number of hours of work and to the requirement of physical effort exerted on the job), regulation of hours, job security and match of skills to knowledge.

Our sample contains only observations of male workers in West Germany from 18 to 60 years of age who are not self-employed in the year of the interview. The GSOEP contains information on 3,305 workers who reported having resigned from their last position. ${ }^{17} \mathrm{We}$ further restrict our sample of voluntary changes to contain only transitions between full-time jobs for whom we have information on the hours agreed-upon in the contract both in the origin and destination jobs. We require weekly agreed hours to lie between 15 and 60 . We also selected job changes in which the respondent had been in his last position for at least a year. We exclude job changes that take place before the individual did his military service or completed his education. Overall, we use information on 743 job changes made by 653

\footnotetext{
${ }^{16}$ Longitudinal panel data sets in the US such as the Panel Study of Income Dynamics contain little information about the consumption of disamenities on the job.

${ }^{17}$ The GSOEP first asks respondents "Has your job situation changed since the beginning of (year prior to the interview)?" The following question is "Why did you leave this job? Which one of the following points applies to you?"

We consider as a "quit" the answer "resigned." See the Data appendix for details on the construction of the sample.
} 
individuals. $^{18}$

The measure of hourly wage is the ratio between last monthly earnings and standard weekly hours, multiplied by 4.33, and it is discussed in the next subsection. The means, standard deviation, min and max of the variables used for the sample are described in Table 1. The average age of quitters is 33 years. Voluntary changers in our sample experience an increase in hourly earnings of $8.5 \%$. In general, a larger fraction of workers report that their conditions improved than the opposite. In particular, only $7 \%$ of changes involve an increase in job insecurity. $32 \%$ of all movers reported that their work load decreased after a voluntary job change. $43 \%$ report an improvement in the regulation of hours. In Table 2, we present average wage changes by changes in characteristics. Interestingly, on average, voluntary job changes that involve an increase in the consumption of disamenities, are followed by real wage increases of about 13\%. Improvements in characteristics are associated to wage changes of about $6 \%$ (work load improvements) to $9 \%$ (improves in job security.) The pattern of wage changes appears to roughly support the presence of compensating wage differentials, although these simple statistics are not conclusive. Section 5 provides a more complete analysis of the relationship between changes in the consumption of amenities and wages. Prior to that, Section 3.1 lays out the empirical specification.

\subsection{Empirical specification}

Let a worker $i$ who is working at job $j$ in moment $t$ for an hourly wage $w_{i j t}$. We assume that workers who report having changed voluntarily their position have received a better offer that increases their level of utility (McLaughlin (1990), argues that a quit is a worker-initiated separation caused by a better wage-draw). Hence, each observation will be a voluntary job change. Based on the discussion in (4.1), we concentrate on four disamenities: work load $\left(D_{j t}^{1}\right)$, flexibility of hours $\left(D_{j t}^{2}\right)$, security on the job $\left(D_{j t}^{3}\right)$, and $\left(D_{j t}^{4}\right)$, the match between worker's knowledge and the skills required on the job. The specification used is the following:

$$
\begin{aligned}
\log \left(w_{i j t}\right)-\log \left(w_{i, j-1, t-1}\right)= & d_{0}+\sum_{k=1}^{4} d_{1}^{k} 1\left(D_{j t}^{k}>D_{j-1 t-1}^{k}\right)+\sum_{k=1}^{4} d_{2}^{k} 1\left(D_{j t}^{k}<D_{j-1, t-1}^{k}\right) \\
& +\gamma_{1} X_{i t}+\gamma_{2} S A T I S F_{i j-1, t-1}+\varepsilon_{i j t}-\varepsilon_{i j-1, t-1}
\end{aligned}
$$

\footnotetext{
${ }^{18} 575$ workers contribute one quit to the sample, 68 workers contribute two quits, 8 workers contribute three quits. 2 workers report 4 quits. The number of quits changes per wave, and attains its maximum in 1992, with 96 cases. The minimum number of quits happened in 1985, with 17 cases.
} 
$d_{0}$ is the expected wage growth of a person who leaves voluntarily a job for another with the same observed level of disamenities. $1\left(D_{j t}^{k}>D_{j-1 t-1}^{k}\right)$ denotes the event "disamenity $k$ is higher in the new job than in the previous one." $d_{2}^{k}$ is the magnitude of the change in the logarithm of the wage following a voluntary change that involves decreasing the consumption of disamenities on the job. Following the discussion in Section 2, if there exists a positive market return to the presence of a disamenity, $d_{2}^{k}$ should be either zero or negative. $d_{1}^{k}$ is the magnitude of the change in the logarithm of the wage following a voluntary change that involves increasing the consumption of disamenities. The second restriction implied by a market that places positive returns to disamenities is that $\left|d_{1}^{k}\right|>\left|d_{2}^{k}\right|$. If both conditions hold, the market return to the presence of a disamenity on the job, $\delta_{k}$, is bounded by $\left|d_{1}^{k}\right|$ and $\left|d_{2}^{k}\right|$

A problem with specification (3.1) is that we do not observe the hourly wage $w_{i j t}$. The GSOEP asks respondents to report the amount of their net earnings last month, including overtime. To construct a measure of hourly wages, there are two questions about hours worked. The first asks about the average number of hours worked on a regular week (not necessarily on the last month), including overtime. The second asks about the number of agreed number of hours, or standard weekly hours. In an analysis on the effect of hours constraints on hourly wages, Hunt (1999) implicitly uses a measure of hourly wages by dividing monthly wages on standard weekly hours, adjusting in the regression for a measure of overtime hours. We follow a similar approach, defining the hourly wage as the ratio of monthly net income to standard hours (multiplied by 4.33). Such measure may bias the hourly wage, in the presence of overtime or undertime in the month of the response. In section 5.1, we include an adjustment for the change in the number of hours of overtime in the regression.

$X_{i}$ contains controls for the education level of the worker at the time of the change, wave-specific dummies, control for marital status and, in some specifications, industry of destination dummies. Human capital models predict that workers with higher levels of education should experience higher wage growth. Wave dummies are included to capture the effect of the cycle on wages and on the composition of quits. Industry dummies capture reflect sectorial differences in union bargaining power (see Daniel and Sofer, 1998) or permanent differences related to efficiency wages. SATISF $F_{i j-1, t-1}$ denotes the difference between the reported level of satisfaction with the present job in the period prior to the change and the 
individual level mean. The discussion in Section 2 argued that the expected wage increase when transiting to a higher work load is positive if the tolerance for disamenities is held constant. We approximate the "tolerance for disamenities" with the variable "satisfaction with the job," that is asked every wave in the GSOEP. ${ }^{19},{ }^{20}$ The rationale is that if amenities are (longitudinally) correlated with satisfaction, workers who consume disamenities on their current job should report levels of satisfaction below their individual mean. ${ }^{21}$

Next, we examine the impact on our estimates of two possible sources of biases.

Subjectivity bias Imagine that a worker leaves a bad match for a better one. That worker might feel more satisfied about the new match, and report that job security, for example, in the new job is actually better than in the previous one, even though it is not the case. Such a response pattern would generate non-classical measurement error, and the estimates of $d_{1}^{k}$ and $d_{2}^{k}$ would be biased. To assess the direction of the bias and for the sake of simplicity, we ignore selection issues, and assume that there are no compensating wage differentials in the labor market. That is, $\ln w_{i f t}=\theta_{f t}$, where $\theta_{f t}$ represents the quality of the match. We assume that workers tend to report better characteristics $D_{f t}^{*}$ if they are in a match with higher productivity, or

$$
\begin{aligned}
& \Delta D_{f t}^{*}=1 \quad \text { if } \quad \Delta \theta_{f t}<k \\
& \Delta D_{f t}^{*}=-1 \quad \text { if } \quad \Delta \theta_{f t}>k_{1} \\
& \Delta D_{f t}^{*}=0 \quad \text { otherwise }
\end{aligned}
$$

Where $k$ and $k_{1}$ are positive scalars. $d_{2}^{k}=E\left(\Delta w_{i f t} \mid \Delta D_{f t}^{*}=-1\right)$. would equal $E\left(\Delta w_{i f t} \mid \Delta \theta_{f t}>\right.$ $k_{1}$ ), a positive number. Similar reasoning would show that $d_{1}^{k}$ is negative. That is, such a

\footnotetext{
${ }^{19}$ Including the wage prior to the change, in addition to the satisfaction variable, had no impact on our results.

${ }^{20}$ Unfortunately, the sample of movers for which we could assign the initial level of disamenities on their initial job is small, compared to the sample of movers we use, that exploits the report of the change in characteristics. In an earlier draft, we imputed measures of the presence of disamenities in the original job using the detailed information in job characteristics in the 1985, 1987, 1989, 1990 and 1995 waves of the GSOEP. Nevertheless, the subsample of workers for whom we had that information was small.

${ }^{21} \mathrm{An}$ alternative approach to the one described in this paper amounts to regressing changes in wages on changes in job characteristics (see, for example, Brown, 1981 and Duncan and Holmlund, 1983). Note that, even after controlling for individual specific ability, a hedonic wage regression in a sample of quitters may not provide a consistent estimate of $\delta$, as the difference between $E(\Delta w)$ and $\delta$ depends on the relative proportion of changes to jobs with better characteristics and worse characteristics (see Solon, 1988, for a similar point.)
} 
pattern of reporting error leads our estimates to be biased against the hypothesis of the existence of a positive return to the presence of disamenities on the jobs.

Misreport of quits The empirical strategy relies on the differentiation between quits and layoffs as observationally different concepts. We discuss below that self-reported quits are less likely to stop working than self-reported layoffs, and also are more likely to report higher satisfaction a year after the change. Yet, some of the quits we find may be "disguised layoffs" Assuming that these workers draw on average worse matches from the distribution of job values, one would expect that their wages fall relative to "true quits", and their consumption of disamenities increases. That is, "false quits" are likely to bias our upward bound on compensating wage differentials toward zero.

\section{The measure of disamenities}

This section explores what characteristics of jobs change when workers report a worse work load, worse regulation of hours and job security following a change of positions. The GSOEP contains two sources of information about job characteristics. In the 1985, 1987, 1989, 1995 and 2001 waves of the GSOEP respondents are asked to report detailed characteristics of their jobs. Namely they are asked whether or not (1) they are exposed to bad environmental conditions (2) shift work is required in their present position (3) the night turn is required in their position (4) their job is physically strenuous, and (5) their work is mentally strenuous. As explained in the previous subsection, the GSOEP also contains a yearly question for job changers in which respondents are explicitly asked to compare characteristics of their jobs. To understand what characteristics underlie the report of worse characteristics we built a sample of workers who report at least a position change during the period 1986-2001. The sample includes reported voluntary moves across firms, changes in jobs across firms when the original position was terminated by the employer and position changes within the firm. Then we compare the workers' report of the change in "work load" and "hours regulations" to the report on the five characteristics in the 1985, 1987, 1989, 1995 and 2001 waves. That sample size is much smaller than the main one used for the wage regression (3.1) because not for all job changers we have the detailed characteristics in the origin and destination job. ${ }^{22}$

\footnotetext{
${ }^{22}$ For example, imagine that a worker quits a job in 1993. In principle, the detailed characteristics on physical effort or environmental conditions were not asked in 1992 nor in 1994 . Hence, we cannot directly impute the (detailed) characteristics of the position held in those two years.
} 
To maximize the sample size, we create a new variable called "position held by the worker." Using the information in the GSOEP, we determine whether or not a worker is holding the same position as last year. Then, we extend the characteristics reported on each of the 1985, 1987, 1989, 1995 and 2001 waves to all the waves in which the individual reports to work in the same position. Finally, we selected all males who (a) report that their current job is different from the one they held the previous year and (b) report characteristics (1) through (5) of both their new "position" and the last one. The sample used for the analysis contains 360 observations on 339 individuals who report a change in the job they held, and provide information on the characteristics of the positions they held.

In the first column of Table 3, we report the coefficients of an OLS regression in which the dependent variable takes value 1 if the worker reports that the work load improved and 0 otherwise on the following variables "reported change in mental stress", "reported change in physical effort," "reported change in environmental conditions," "reported change in whether doing shift work." Each of these variables takes value 1(-1) if the worker reports that in the new position, the reported presence of the disamenity is less (more) frequent than in the previous position, and 0 if the disamenity is equally present in the prior and current position. We also control for demographic variables, like a second-order polynomial in the age of the worker at the time of the job change, in deviations from 30, and a separate intercept for non married individuals. Finally, we also include a separate intercept that takes value 1 if the worker changes to a blue collar position. ${ }^{23}$

Workers who report that their new job is less physically strenuous than their last one are $9 \%$ more likely to report that the work load is better in their new job than in the previous one. Similarly, workers who increase their number of actual hours of work in the destination job relative to their former one by 10 hours are $2.3 \%$ more likely to report that the work load decreased after the change. The latter estimate is not significantly different from zero at the $10 \%$ confidence level, though. ${ }^{24}$ The estimates are robust to alternative specifications, like Probit (Column 2.) Column 3 shows the coefficients of a regression of the event "the work load in the new position is worse than in the previous one" on the same set of regressors. Again, exerting less physical effort in the new job decreases the probability of reporting that

\footnotetext{
${ }^{23}$ The omitted group is a 30 year-old worker, switching to a white collar position without any change in the characteristics detailed in waves $85,87,89,95$ and 2001 of the GSOEP.

${ }^{24}$ This estimate is somewhat sensitive to functional form, introducing a dummy for the increase in the number of hours yields that an increase in the number of hours makes it $9 \%$ more likely to report a better work load, and the estimate is significant at the $5 \%$ confidence level.
} 
the new job has a worse work load by $9 \%$. Finally, workers who increase their number of actual hours of work in the new job by 10 hours are $4 \%$ more likely to report that the new job has a worse work load than the previous.

The first column in Table 4 presents the results of an OLS regression in which the dependent variable takes value 1 if the worker reports that the regulation of hours in the present job is better than in the last one. The set of regressors is the same as in Table 3, but we introduce a measure of the number of hours of work that correspond to overtime. The rationale is that holding the total number of hours constant, working more hours overtime may be an undesirable characteristic of a job to the extent that overtime may involve work in non-central hours of the day - see Hamermesh, (1999b). The probability of reporting "better regulation of hours" decreases by $5 \%$ if the new job requires 10 hours of work more than the previous one. In the Probit specification, holding total hours of work constant, an increase of 10 hours of overtime diminishes the probability of reporting a better regulation of hours by 12 per cent (the coefficient is significantly different from zero at the 10.3 per cent confidence level). ${ }^{25}$ The regressions in which the dependent variable is "work regulation worsens" confirm the previous results.

Other results worth noting are that the probability of reporting a worsening of the work load is hump-shaped over the life-cycle. It increases up to age 35 and declines afterwards. For the regulation of work hours, the pattern is less clear. Second, workers who report working as blue collars are less likely to report a worsening of working conditions when changing positions, perhaps because their initial jobs are more likely to involve these disamenity.

Our summary of the findings in this section is that the variation in work load reported by job changers is correlated with variation in physical effort and actual hours of work. These are disamenities extensively studied in the existing literature on compensating wage differentials (see Daniel and Sofer, 1998 or Duncan and Holmlund, 1983). Also, workers are more likely to report that the regulation of hours has improved if their new job involves less amount of overtime than the previous one.

\footnotetext{
${ }^{25}$ We have also ran regressions of the other variables "change in advancement possibilities," "change in job security" and "change in fringe benefits" on the same set of regressors. Variation in job security is unrelated to these disamenities, and we interpret that it is most likely related to the probability of losing a job.
} 


\subsection{Do these characteristics affect satisfaction with the job?}

The results in Section 2 only hold to the extent that disamenities enter the utility of a worker with an unambiguous negative sign. Given that it is difficult to make an a priori assessment of whether or not a given characteristic affects the utility of a worker, in this subsection we make a direct test using individual reports of job satisfaction. In particular, if workers diminish their utility when consuming disamenities on the job, we should observe that an improvement in the working conditions, holding earnings constant, is associated to an increase in the reported satisfaction of that worker.

We study of the evolution of satisfaction with the job after a change in the amenities consumed on the job. Changes in job characteristics are only reported around a change in the position in the GSOEP, either voluntary across firms, changes within the firms or contracts terminated by the employer. We use a sample in which every voluntary transition between full time jobs contributes one observation. The sample contains 1,164 voluntary job changes belonging to 964 individuals. The specification we run is the following

$$
\begin{aligned}
\Delta U_{i t}^{*}= & \gamma_{0}+\gamma_{1} \Delta E A R N_{i t}+\gamma_{2} \Delta W O R K_{i t}+\gamma_{3} \Delta H O U R S_{i t}+\gamma_{4} \Delta S E C_{i t}+ \\
& \gamma_{5} \Delta B E N_{i t}+\gamma_{6} \Delta S K I L L_{i t}+\gamma_{7} \Delta C O M M U T E_{i t}+ \\
& \theta X_{i t}+v_{i t}
\end{aligned}
$$

$i$ indexes individuals and $t$ denotes the wave in which the job change is observed. $\Delta U_{i t}^{*}$ denotes a latent variable indicating the change in individual's utility between the period prior to a job change and the following. $\triangle E A R N_{i t}$ takes value 1(-1) if the earnings are higher (lower) in the new job than in the previous one. It takes value zero if earnings are about the same in the new job and in the last one. The variable $\Delta W O R K_{i t}$ takes value $1(-1)$ if the new job after a voluntary change has a better(worse) work load than the previous one, 0 if the work load is the same in both workers. The coding for the rest of the variables is the same. $\triangle H O U R S_{i t}$ denotes the regulation of hours, $\triangle S E C_{i t}$ denotes job security, $\triangle B E N_{i t}$ denote fringe benefits. $\triangle S K I L L_{i t}$ takes value 1(-1) if the individual can use his skills and knowledge more than in his last job, and zero if about the same. Finally, $\triangle C O M M U T E_{i t}$ denotes length of trip from and to work. $X_{i t}$ includes the deviation of age from 30 and calendar year dummies. (4.1) is estimated for the sample of individuals who report at least having experienced a voluntary job change. We estimate this model using an ordered Logit 
model in which the utility of the individual is proxied by the reported level of satisfaction with the job. $\gamma_{1}$ can be interpreted as the increase in satisfaction associated to an improvement in earnings following a voluntary job change. A positive sign indicates that the presence of a non-monetary amenity on the job raises the utility of the worker, so that he can potentially forego earnings to achieve such characteristic. Reported satisfaction in the GSOEP variable takes 10 values (from 0, very unsatisfied to 10, very satisfied.) Consequently, the variable "change in satisfaction" takes at most 20 values.

The first column in Table 5 contains the coefficients $\gamma_{1}, . ., \gamma_{7}$ in regression (4.1). Given that the magnitudes of these coefficients do not have a clear interpretation, we focus on their signs. Column 1 in Table 5 presents a specification without covariates. The coefficients of change in earnings, work load and change in job security are positive and significantly different from zero. That is, an improvement in any of these characteristics is associated with an increased report of satisfaction with the job after a voluntary job change. Improvements in the regulation of hours of work results in an increase of satisfaction on average. Once we control for the change in earnings, changes in fringe benefits and commuting time seem not to affect satisfaction. ${ }^{26}$

The coefficient of "better use of skills," is a strong predictor of the evolution of satisfaction following a job change, the estimate being three times as large as the coefficient on the change in earnings. While this specific characteristic of a job has not been traditionally considered in the compensating wage differentials literature, it seems to be strongly correlated with individual reported satisfaction, holding income constant.

Clark (2001) shows evidence from UK that the current level of satisfaction is a good predictor of future quitting behavior. If workers who are more dissatisfied with their current job are more likely to report both improvements in any given characteristic and in satisfaction after a job change, our estimates would reflect heterogeneity in satisfaction reports, rather than the causal effect of characteristics on satisfaction. To mitigate such biases, in Table 5, Column 2 we introduce a control for the level of satisfaction with the job before the change. ${ }^{27}$ The pattern of coefficients are robust to the inclusion of indicators of the two-digit

\footnotetext{
${ }^{26} \mathrm{~A}$ possible reason of the fact that fringe benefits like health benefits do not affect satisfaction is that, in Germany and unlike the US, health benefits are available through the public sector. Hence, workers may not be as concerned about firm-specific provision.

${ }^{27}$ Introducing the mean level of satisfaction over the waves in which the individual was in the previous job does not change the results. In earlier versions of this paper, we used an event study analysis to analyze the effect of the characteristics on satisfaction, using OLS models with an individual fixed effect. The results basically the same.
} 
industry prior to the job change, and demographic and human capital variables. Hence, in our analysis, we focus on the effect of work load, regulation of hours, job security and match between the skills of a worker and the requirements in the position.

\section{$5 \quad$ Wage regressions}

The coefficients in Table 6 presents the main results of the paper, with the results of regression (3.1) for workers who reported having changed jobs voluntarily. The dependent variable is the change in the logarithm of hourly wages after the job change, computed as the ratio of monthly income and "agreed" hours. All models include age of the worker at the time of the job change in differences from 30, age minus 30 squared and wave specific intercepts. In specifications II-IV, we also include three dummies with the educational attainment of the worker at the time of the job change. The constant term in the regression is an estimate of the increase in log hourly wage following a voluntary job change for a 30 year old person, who has completed vocational training but not college education, and who changed jobs in 1990. The standard errors are corrected for heteroscedasticity in wage growth and arbitrary correlation within changes of the same worker. We exclude (log) wage increases exceeding 1 and -1.to avoid the influence of a small set of large wage changes on our estimates. ${ }^{28}$ Finally, we do not use nonlinear specifications. One reason is that the main effects in (1) are all binary. Second, sample size considerations prevent us from exploring interactions between the main effects.

The first column of Table 6, reports the signs predicted if markets place monetary premia on the presence of disamenities on the job. The discussion in Section 2 suggested two main results. If markets place premia on the consumption of disamenities on a job, then voluntary changes to jobs involving a fall in the consumption of disamenities should be associated to either constant wages or to relative wage decreases. Second, if a market return to the presence of a disamenity exists, increased consumption of disamenities should be associated to relatively high wage increases, and improvements in the consumption of disamenities should be related to low wage falls.

The coefficient of "better work load" in the second row of model I, is $-0.044(.020)$. We reject that the number is positive at any popular confidence level, consistent with a

\footnotetext{
${ }^{28}$ Trimming the sample results in a dramatic reduction of standard errors of the coefficient of interest (by more than $25 \%$ ). The point estimates are not very sensitive to trimming.
} 
market that places a return on the "work load" of a job. The estimate implies that, relative to quitters who do not change their work load, wages decrease by $4.4 \%$ for workers who change to jobs with better work load. The coefficient of "worse work load" in the first row of model I, is .051 (.024). The wage increase for a worker who changes to a job with a worse work strain is 5.1 percent higher than the wage increase of a similar worker who did not experience a worsening of the work load after the change. Also, according to the model in Section 2, the $5.1 \%$ wage increase following a change to a job with worse work load provides an upper bound on the market return to the work load in a job. Finally, the key prediction is that the magnitude of the (log) wage increase following a voluntary job change that involves a worsening of the work load is bigger in absolute value than the magnitude of the wage decrease following a voluntary job change involving an improvement in the work load. For the case of the work load, the empirical results are consistent with the hypothesis: the relative associated wage increase of $5 \%$ following an increase in work load exceeds the relative associated wage decrease of $3 \%$ (although we cannot reject that both numbers are statistically equal). ${ }^{29}$

As discussed in Section 2, a report of "worse hours regulation" is more likely if the worker reports doing more often overtime work. In the first column of Table 6 , the estimate of "worse hours regulation" is .046 (.027), positive, and significantly different from zero at the 10 per cent confidence level. The point value varies across specifications. Taken at face value, the point estimate implies that the wage increase for a worker who changes to a job with "worse hours regulation" is 4.6 percent higher than the wage increase of a similar worker who did not experience a worsening of the regulation of hours after the job change. The coefficient of "better regulation of hours" is .029 (.021). The coefficient is large, although not significantly different from zero at the 10 per cent confidence level. The hypothesis that there is a penalty on jobs with bad regulation of hours is not clearly supported by this specification.

Given the strong impact of changes in job security on worker's satisfaction, we find it surprising that the coefficients of the variables related to "security on the job" in Table 6 do not show that workers trade-off wages and security on the job. The coefficient on improved job security is .017 (.18), positive, but small and not significantly different from zero. There is some controversy about the existence of a trade-off between job security and wages in

\footnotetext{
${ }^{29}$ Note that downward wage rigidity is unlikely to generate the asymetry in the absolute value of wage changes: adding up the constant (.056) and the coefficient of "better work load" (-.04), there is a $2 \%$ average wage increase for workers who decrease their consumption of disamenities
} 
European countries, after the introduction of fixed-term contracts in Germany, Italy, France and Spain. ${ }^{30}$ Fixed-term contracts could only be renewed at the will of the firm, and the no-renewal did not entail severance costs, and a worker holding one of these contracts faced higher risks of losing his or her job than a worker with a permanent contract. De la Rica (2003) documents a negative relationship between holding one of these contracts and wage levels in Spain. The pattern of voluntary job changes provides little evidence of market segmentation in insecure low-paying jobs and secure high-paying jobs.

The coefficient of "worse match between skills of the worker and skills required on the job" in the first specification of Table 6 is .065 (.027). To be induced to work in jobs that involve skills less akin to theirs, workers require a wage increase of $6.5 \%$, relative to workers who change to a job requiring similar skills than the current one. Conversely, workers who change to jobs that involve a better matching of their skill to the requirements experience wage increases of about $3.3 \%$, significantly different from zero at the 10 percent confidence level. Teulings and Gautier (forthcoming) propose a model with search frictions that contradicts this finding. In their model, jobs vary over the skill requirements, and workers over their human capital, where workers who have a higher level of human capital have higher productivity. Teulings and Gautier show that search frictions make workers accept jobs that are not perfect matches to their ability, creating a concave relationship between wages and workers skills. A possible interpretation of the results in Table 6 is that there are jobs that require skills that workers do not typically acquire in the formal educational system. The labor market places a wage premia on those jobs, as workers find it costly to learn those new skills (see Table 5).

The second column in Table 6 adds the number of years of education and three separate intercepts for the educational level of the worker at the time of the job change (not shown). We also include a separate intercept for workers whose education level is not known. The basic results are not affected.

Model III adds indicators of the (two-digit) industry of destination after the job change. The rationale is to examine whether or not our estimates are picking up the effect of differential union power across industries, given that the German wage setting system relies

\footnotetext{
${ }^{30}$ For the German case, see Winkelmann and Zimmerman (1998). They claim that job stability did not decrease over the period. There is a further issue about fixed-term contracts. These contracts may be used as cheap screening devices by firms that cannot observe the productivity of workers (usual contracts have firing costs that make such screening process expensive). The theory of compensating differentials assumes that, once a match is made, characteristics are observed to both parties.
} 
on industry-wide agreements ( Hunt, 1999). ${ }^{31}$ The coefficients are similar and we do not comment them in detail. Model IV includes indicators of whether or not the firm of origin or destination had more than 2,000 employees, to capture permanent wage differences related to costs of monitoring, as stressed by efficiency wage theories. It also adds controls for changes in other job characteristics, like commuting time, fringe benefits and changes in advancement possibilities. The rationale is that we have only identified a subset of the amenities that change when individuals change jobs. If other unobserved amenities change when individuals switch jobs, and these unobserved variables are correlated to the amenities we consider, our estimates would be biased. Once we condition for other characteristics of jobs and industry dummies, the coefficient on "improved match of skills and knowledge required" falls to .023 (.020). Possibly, the .033 coefficient of the "better match of skills and knowledge" in Model 1 is picking up industry effects.

In our view, the results in Table 6 do not support the hypothesis of negative associations of disamenities and wages (or "segmented labor markets"). Those theories predict that average wage changes from jobs with disamenities to jobs with them ought to be positive and significantly different from zero. Rather, our results support the hypothesis that the labor market places a wage premia to jobs that require physical strain, jobs that involve skills that workers do not typically have and, more tentatively, on jobs with bad regulation of hours. Interestingly, the hedonic regression method applied to GSOEP yields estimates that reverse the theory of compensating wage differentials (see Lorenz, 1989).

\subsection{Robustness checks.}

Controlling for overtime The hourly wage measure used in Table 6 may be mismeasured because of over- or undertime. Increases of overtime work may increase the hourly wage in a job, and are possibly correlated with the regulation of hours and the work load in the job (see Table 2). Unfortunately, the GSOEP does not contain enough information to recover the exact hourly wage. This section introduces a correction to correct for biases due to overtime work, following Hunt (1999). The GSOEP contains information on monthly earnings $\left(w_{M}\right)$. It also contains a measure of monthly hours: "agreed-upon weekly hours" $\left(h_{s}\right)$ and "actual

\footnotetext{
${ }^{31}$ One could argue that differential bargaining union power among industries may change not only the wage growth, but also the relationship between wage changes and changes in disamenities (see Daniel and Sofer (1998) and Duncan and Stafford (1980) for different theoretical results on the effect of differential union power on the link between wages and disamenities). Our view of these theories is that they do not account the possibility of job changes between industries, that can potentially erode industry-specific returns.
} 
hours in a normal week." To fix ideas, monthly wages can be written as follows

$$
w_{M}=w\left[4.33 h_{s}+(1+p) O T_{M}-U T_{M}\right]
$$

$w$ is the hourly wage, the variable of interest. $p$ is the overtime premium and $O T_{M}\left(U T_{M}\right)$ is the amount of overtime (undertime) last month. The GSOEP reports $w_{M}$ and $h_{s}$, but $U T$ and $O T_{M}$ are both unobserved. Let us rewrite (3.1) as follows

$$
\Delta \log (w)=\alpha+\beta x
$$

Manipulating (5.1) as in Hunt (1999), one can obtain the following approximation to $(5.2)$

$$
\Delta \log \left(w_{M} / 4.33 h_{s}\right)=\alpha+\beta x+(1+p) \Delta \frac{O T_{M}}{4.33 h_{s}}-\Delta \frac{U T_{M}}{4.33 h_{s}}
$$

Hunt approximates $O T_{M}$ by the measure of overtime work in the GSOEP, multiplied by 4.33 , and makes no correction for undertime $U T_{M}$. We follow a similar strategy, but place no restrictions on the coefficients of $\Delta \frac{O T_{M}}{4.33 h_{s}} \cdot{ }^{32}$ In Column 1 of Table 7 , the coefficient of the indicator variable "work load increased" is .044 (.024), slightly smaller than the .051 (.024) estimate in Table 6. The coefficient of the variable "work load decreased" it is -.046 (.020), slightly larger in magnitude. Once we control for industry dummies and size firm controls, the lower bound goes to -.035 (.02). All these coefficients are significant at the 10 percent confidence level. Contrary to the theory of compensating wage differentials, the coefficient of the variable "the regulation of hours improved" is .035 (.020), positive and significantly different from zero at the 10 percent confidence level. Hence, once we condition on overtime measures, the evidence for monetary returns to jobs with bad regulation of hours is mixed. ${ }^{33}$

\footnotetext{
${ }^{32}$ The measure of monthly overtime is not available for 1987 . Given the small sample size, we replaced overtime work in that year by the difference between actual hours of work and agreed-upon hours.

${ }^{33}$ The results in Section 2 to bound the wage penalty. It can be shown that $\left|\widehat{d}_{2}^{\text {hours }}\right|$ equals $\delta+E_{\Delta \varepsilon}(\Delta \varepsilon \mid \Delta \varepsilon \geq$ $-Z-\delta, Z$ ), where $\delta$ is the absolute value of the wage penalty on jobs with bad regulation of hours, and $E_{\Delta \varepsilon}(\Delta \varepsilon \mid \Delta \varepsilon \geq-Z-\delta, Z)$ is a positive selection term. According to the result in Column 4 of Table 7 , $\widehat{d}_{2}^{\text {hours }}$ equals .035 in absolute value. That, is, .035 is an upper bound on the wage penalty $\delta$. Also, $\widehat{d}_{1}^{\text {hours }}$ is positive and larger in absolute value than $\widehat{d}_{2}^{\text {hours }}$. Hence, these results are consistent with a zero market return to the presence on bad regulation of hours.
} 
Are we capturing promotions? There is a literature relating job mobility to learning processes in which firms learn about the (unobserved) productivity of their workers. For example, Malcomson and MacLeod (1988) derive a model of the relationship between workers and firms in which firms incentive their workers by offering position-related wages. Most productive workers self-select into these positions because their cost of effort is lower. These models also predict that, early in their careers, more able workers self-select into higher ranked jobs and increase their wages by exerting increasing effort. Less able workers may be demoted from their previous position, experiencing opposite changes. In such case, characteristics on the jobs and wages change in ways that do not necessarily reflect trade-offs. We use these theories to falsify our empirical strategy. A possible interpretation of our results is that the variation in work load across positions is related to increasing effort. Were that the case, the positive correlation between increases in work load and wage gains would be caused by firm learning devices, rather than by compensating wage differentials.

We test such hypothesis running regression (2) on a sample of workers who change jobs and stay in the same firm. Following the literature on wage growth within the firm (McCue, 1996), we assume that position changes within the firm are mainly related to promotions and do not necessarily reveal worker's preferences for job amenities. Our test is the following: if we find the same pattern of correlations between wages and our measure of disamenities in specification (2) on a sample of voluntary changers (who we assume that reveal preferences about attributes) and on a sample of within-firm changes (who we assume that basically go through promotions and demotions,) we may worry that our empirical strategy is really capturing promotions. ${ }^{34}$

Table 8 presents the results of regression (2) on a sample of 316 changes within the firm, and the summary statistics of the sample, in the fifth column. In Column I, the coefficient on "work load increased" is .007 (.02). Hence, a change in the position within the firm that involves increasing the work load does not involve a wage change. The coefficient on "work load decreased" is negative -.025 (standard error: .024), smaller to the corresponding coefficient in Table 6, albeit less precise. The third hypothesis in Section 2 that, in absolute value, the wage change following a worsening of the load is higher than the wage change following an improvement in conditions is rejected by the data. The same hypothesis is

\footnotetext{
${ }^{34}$ Our maintained hypothesis is that job characteristics vary more between than within firms. Hence, workers who want to change the amount of disamenities present on their job are more likely to change firms than to change positions within the firm.
} 
also rejected for the variable "regulation of hours", as the coefficient on "worse regulation of hours" is .005 (standard error: .022), and the coefficient of "better regulation of hours" is -.053 (standard error: .026). In the case of the variable "match of worker's knowledge and skills required by the job", the signs are reversed with respect to Table 6. Summarizing, we interpret from the results in Table 8 that the market returns to a heavy work load, mismatch of worker's knowledge and job skills and regulation of hours is not likely to be generated by promotions.

Are quitters observationally different from displaced workers? Our identification strategy depends crucially on the self-report of a "resigning" from a job indicating voluntary job change, as opposed to a lay-off, for example. We have compared the evolution of employment status and satisfaction for workers who report having left their job voluntarily and workers whose job was terminated by the employer. We find that: (a) Out of 2,188 workers in the waves considered who report that their last position was terminated by the employer, 36\% (785) went either to unemployment or non employment. The corresponding results for workers who report having resigned their jobs is $7 \%$ out of 3305 cases (b) Using an event-study analysis, we find that reported satisfaction of workers whose job was terminated by the employer decreases after the job change, while the satisfaction of workers who say they changed voluntarily increases after the change. Hence, we interpret that, while some quits may be disguised lay-offs, on average, both types of moves are observationally different.

\section{Conclusion}

This paper tests for the presence of wage returns to the presence of disamenities in a job, exploiting the idea that workers who change jobs voluntarily, express their relative preference between packages of wages and nonmonetary characteristics in their origin and destination jobs. Hence, if the market creates a monetary return to the presence of a disamenity (a testable assumption), the average wage change of workers who quit their job, to take an-

other with higher (lower) consumption of disamenities, provides an upper (lower) bound on the market return to the disamenity. This method has the advantage of not relying on variables that account for selectivity of workers into jobs, and, at the same time, do not affect wages. In addition, the proposed estimation method is robust to the presence of unobserved heterogeneity in worker's productivity, as long as it is constant over time. 
We implement this strategy using a panel of German workers. We consider physical effort requirements, regulation of working time, matching of worker's knowledge and required skills, and job insecurity as disamenities. Even in a labor market like the German, commonly viewed as very rigid, we find evidence of compensating wage differentials. The estimated market return to the presence of a work strain in a job (a variable correlated with requirements of physical effort) is between 3.5 and 5\%. The market return to bad regulation of hours ( a variable correlated with requirements of overtime work) is between zero and 4\%, although, the estimate is not always significantly different from zero. Jobs, requiring unusual skills, pay a wage premium bounded between 0 and $6 \%$. Finally, we do not find any systematic relationship between wages and job security.

Our approach yields estimates of market equilibrium relationships, which is the first step in recovering deep structural parameters of the utility function of workers (their marginal willingness-to-pay) and the cost function of firms (their marginal costs of offering disamenities.) Ultimately, in order to conduct policy simulations, we would be interested in structural parameters of the utility function of the worker and the cost function of firms. That task is left for future research.

\section{References}

[1] Altonji, J. and C. Paxson (1988) "Labor Supply Preferences, Hours Constraints, and Hours-Wage Trade-Offs." Journal of Labor Economics. Vol 6(2).

[2] Abraham, K. and Houseman, S. (1995) "Earnings Inequality in Germany" in Differences and Changes in Wage Structure, Lawrence Katz and Richard Freeman, eds. Chicago: University of Chicago Press.

[3] Brown, C. (1980) "Equalizing Differences in the Labor Market." Quarterly Journal of Economics 94(1).113-134

[4] Clark, A.(2001) "What really matters in a job? Hedonic Measurement Using Quit Data." Labour Economics. Vol. 8. p 223-242

[5] Daniel, C. and Sofer, C. (1998) "Bargaining, Compensating Wage Differentials and Dualism in the Labor Market: Theory and Evidence from France." Journal of Labor Economics. Vol 16(3) 
[6] De la Rica, S. (2003) "Wage Differentials Between Permanent and Temporal Workers: The Impact of Firm and Occupational Segregation" manuscript, Universidad del Pais Vasco.

[7] Duncan G., and Holmlund, B.(1983) "Was Adam Smith Right After All? Another Test of the Theory of Compensating Differentials" Journal of Labor Economics Vol 1(4): 366-79

[8] Duncan, G., and Stafford, F. (1980) "Do Union Members Receive Compensating Wage Differentials?" American Economic Review 70(3): 355-71

[9] Ekeland, I., Heckman, J., and Nesheim, L. (2003) "Identification, and Estimation of Hedonic Models" NBER Working paper 9910,

[10] Gronberg, T. and Reed, W., (1994) “Estimating Worker's Marginal Willingness to Pay for Job Attributes Using Duration Data" Journal of Human Resources 29. 911-931.

[11] Hamermesh, Daniel S. (1999a) "Changing Inequality in Markets for Workplace Amenities." The Quarterly Journal of Economics. Vol. 114 (4). p 1085-1123.

[12] Hamermesh, Daniel S. (1999b) "The Timing of Work over Time" The Economic Journal, CIX: 37-66.

[13] Hunt, J. (1999) "Has Work Sharing Worked in Germany?" The Quarterly Journal of Economics Vol 114: 117-148

[14] Hwang, H., Reed, W., and Hubbard,C. (1992) "Compensating Wage Differentials and Unobserved Productivity," Journal of Political Economy: 835-858.

[15] Hwang, H., Reed, W., and Mortensen, D. (1998) "Hedonic Wages and Labor Market Search" Journal of Labor Economics. Vol 16(4): 815-847.

[16] Lorenz, W. and J. Wagner (1989) Kompensierende Lohndifferentiale und geschlechtsspezifische Einkommensdiskriminierung. In: K. Gerlach and O. Huebler (eds.) Effizienzlohntheorie, Individualeinkommen und Arbeitsplatzwechsel.

[17] Lucas, R. (1977) "Hedonic Wage Equations and Psychic Wages in the Returns to Schooling" American Economic Review vol. 67(4): 549-58. 
[18] Lang, K. and Majumdar (forthcoming) "The Pricing of Job Characteristics when Markets Do Not Clear: Theory and Policy Implications" International Economic Review.

[19] Malcomson and MacLeod B. (1988) "Reputation and Hierarchy in Dynamic Models of Employment" Journal of Political Economy 96(4): 832-54.

[20] McLaughlin K. (1991) "A Theory of Quits and Layoffs with Efficient Turnover" Journal of Political Economy 99(1): 1-29.

[21] McCue, (1996) "Promotions and Wage Growth" Journal of Labor Economics 14: 175206.

[22] Melow, W. and Sider, H. (1983) "Accuracy of Response in Labor Market Surveys: Evidence and Implications" Journal of Labor Economics 1(4): 331-44.

[23] Olson, C. (2002) "Do Workers Accept Lower Wages in Exchange for Health Benefits?" Journal of Labor Economics Vol. 20(2): S91-114.

[24] Rosen, H. (1986) "The Theory of Equalizing Differences" In Handbook of Labor Economics Vol 1, edited by O. Ashenfelter and R. Layard. Amsterdam. Elsevier.

[25] Solon, G. (1988) "Self-selection biases in estimating longitudinal wage changes" Economics Letters 28: 285-90.

[26] Teulings, C. and Gautier (forthcoming) "The right man for the job" Review of Economic Studies.

[27] Usui (2003) "Wages, Non-Wage Characteristics and Predominantly Female Jobs" manuscript, Wayne State University.

[28] Winkelmann, R., and Zimmermann K., (1998) "Is Job Stability Declining in Germany? Evidence from Count Data Models" Applied Economics 30: 1413-1420.

[29] Weiss, Y. (1976) "The Wealth Effect in Occupational Choice" International Economic Review 17(2): 192-20\%. 


\section{Appendix 1: Proof of proposition 1}

This appendix proves that, when markets place premia on disamenities, $\delta>0$, (the absolute value of) average wage changes from jobs without disamenities to jobs with disamenities exceeds the (absolute value of) average wage changes from jobs with disamenities to jobs without them.

Consider the following moment, defined in the text.

$$
E\left(\Delta w \mid Q=1, D_{1}, D_{0}\right)=d_{0}+d_{1} 1\left(D_{1}>D_{0}\right)+d_{2} 1\left(D_{1}<D_{0}\right)
$$

Where $d_{1}$ and $d_{2}$ can be defined as follows, using the market equilibrium relationship between wages and amenities.

$$
\begin{aligned}
& d_{1}=\delta+E_{\Delta \varepsilon}(\Delta \varepsilon \mid \Delta \varepsilon>Z-\delta) \\
& d_{2}=-\delta+E_{\Delta \varepsilon}(\Delta \varepsilon \mid \Delta \varepsilon>-Z+\delta)
\end{aligned}
$$

Straightforward computations imply that

$$
\begin{aligned}
\left|d_{2}\right| & =\left|E_{\Delta \varepsilon}(\Delta \varepsilon \mid \Delta \varepsilon>-Z+\delta)-\delta\right|=\left|E_{\Delta \varepsilon}(\Delta \varepsilon \mid \Delta \varepsilon>\delta-Z)-(\delta-Z)-Z\right|= \\
|A-Z| & \leq|-Z|=Z
\end{aligned}
$$

Where $A=E_{\Delta \varepsilon}(\Delta \varepsilon \mid \Delta \varepsilon>-Z+\delta)-(\delta-Z)$ The first equality derives from the definition of $d_{2}$. The second equality just adds and substracts $Z$. The inequality follows from the fact that $E_{\Delta \varepsilon}(\Delta \varepsilon \mid \Delta \varepsilon>-Z+\delta)$ is a positive number that cannot be lower than $\delta-Z$. Hence, $A$ must be positive. Finally, $A-Z$ must be smaller in absolute value than $Z$, as both $A$ and $Z$ are positive numbers. then Similar computations imply that

$$
\begin{aligned}
\left|d_{1}\right| & =\left|\delta+E_{\Delta \varepsilon}(\Delta \varepsilon \mid \Delta \varepsilon>Z-\delta)\right|=\left|\delta+E_{\Delta \varepsilon}(\Delta \varepsilon \mid \Delta \varepsilon>Z-\delta)\right| \\
& \geq|\delta+Z-\delta|=Z
\end{aligned}
$$

Hence, if $\delta>0\left|d_{2}\right|<\left|d_{1}\right|$ and $d_{1}>\delta$

(ii) If $d_{2} \leq 0,-\delta+E_{\Delta \varepsilon}(\Delta \varepsilon \mid \Delta \varepsilon>-Z+\delta) \leq 0$, and, given that $E_{\Delta \varepsilon}(\Delta \varepsilon \mid \Delta \varepsilon>-Z+\delta) \geq 0$, $\left|d_{2}\right|<\delta$ 


\section{Data appendix: Sample of quitters}

We first use the question "Has your job situation changed since the beginning of (last year)?

1.Changed position.

2.Job with new employer

3.Became self-employed

4. Gone back to work after a break

5.Took up a job for the first time in my life

The first selection method is to use only individuals who have a job with a new employer (answer 2). We identify quits using the question. "Why did you leave this job? Which one of the following points applies to you?"

1. Given notice

2. Job ended automatically/time limit agreed upon before

3. Training over

4. Resigned

5. Business relation ended

6. By my own request transferred within the firm

7. Sent to another position by the firm

8. Own business given up/family business dissolved

9. Other

We consider as a "quit" the answer "resigned." 3,502 male individuals between 18 and 60 years of age responded that they "resigned" their job between 1984 and 2001. After adjusting for the possible double-counting of quits induced by the wording of the first question (Winkelmann and Zimmermann,(1998)), we have 3,305 observations of quits. 1,712 of these quits involved a position in which the worker was not in a full-time job, and in 610 cases, we had quits from positions with tenure less than one year. Hence, we are left with 1,423 quits. We could define hourly wages for 898 cases, either because of missing values of income in the present or in the last year or because of no information on standard hours in the present or in the last year. We drop quits to or from self-employed positions, and quits that involve wage changes higher than 2.71 times the previous wage or smaller than .37 times the previous wage, obtaining a sample of 856 cases. After removing workers whose origin or destination jobs had hours agreements below 15 hours a week or above 60 hours, we obtain a sample of 838 cases. Finally, we drop 95 quits that involve positions in East Germany. 
Table 1: Descriptive statistics of the sample of voluntary changers across firms

\begin{tabular}{|c|c|c|c|c|}
\hline Variable & Mean & Std. Deviation & Minimum & Maximum \\
\hline Net Monthly Earnings in destination job & $2,892.81$ & $1,202.82$ & $1,045.3$ & $11,470.22$ \\
\hline Agreed hours in destination job & 39.22 & 3.02 & 20 & 60 \\
\hline Hourly wage in destination job & 17.43 & 7.04 & 6.62 & 66.22 \\
\hline Log hourly wage increase & .085 & .237 & -.9876 & .9861 \\
\hline Age & 32.53 & 7.43 & 20 & 58 \\
\hline Single & .35 & .48 & 0 & 1 \\
\hline Years of education & 11.93 & 2.51 & 7 & 18 \\
\hline Vocational School & .58 & .49 & 0 & 1 \\
\hline No vocational School & .12 & .32 & 0 & 1 \\
\hline College degree & .16 & .36 & 0 & 1 \\
\hline Education missing & .14 & .35 & 0 & 1 \\
\hline Satisfaction with the job -previous job, from 0 to 10 & 6.32 & 2.45 & 0 & 10 \\
\hline Satisfaction with health -prior to change, from 0 to 11 & 7.49 & 1.91 & 0 & 10 \\
\hline \multicolumn{5}{|c|}{ Reported characteristics of new job, compared to previous one } \\
\hline New job has higher wage & .66 & .47 & 0 & 1 \\
\hline New job has lower wage & .10 & .30 & 0 & 1 \\
\hline New job has better work load & .36 & .48 & 0 & 1 \\
\hline New job has worse work load & .21 & .41 & 0 & 1 \\
\hline Hours regulation in the new job is better & .44 & .50 & 0 & 1 \\
\hline Hours regulation in the new job is worse & .16 & .37 & 0 & 1 \\
\hline New job is more secure & .38 & .49 & 0 & 1 \\
\hline New job is less secure & .06 & .24 & 0 & 1 \\
\hline New job involves more use of skills & .41 & .491 & 0 & 1 \\
\hline New job involves less use of skills & .16 & .364 & 0 & 1 \\
\hline New job has better fringe benefits & .35 & .47 & 0 & 1 \\
\hline New job has worse fringe benefits & .10 & .30 & 0 & 1 \\
\hline New job involves less time to commute & .34 & .47 & 0 & 1 \\
\hline New job involves more time to commute & .33 & .47 & 0 & 1 \\
\hline Wave 85 & .024 & .15 & 0 & 1 \\
\hline Wave 86 & .042 & .20 & 0 & 1 \\
\hline Wave 87 & .05 & .22 & 0 & 1 \\
\hline Wave 88 & .06 & .25 & 0 & 1 \\
\hline Wave 89 & .06 & .24 & 0 & 1 \\
\hline Wave 90 & .08 & .27 & 0 & 1 \\
\hline Wave 91 & .08 & .27 & 0 & 1 \\
\hline Wave 92 & .11 & .31 & 0 & 1 \\
\hline Wave 93 & .04 & .20 & 0 & 1 \\
\hline Wave 94 & .02 & .13 & 0 & 1 \\
\hline Wave 95 & .04 & .20 & 0 & 1 \\
\hline Wave 96 & .05 & .22 & 0 & 1 \\
\hline Wave 97 & .04 & .20 & 0 & 1 \\
\hline Wave 98 & .036 & .184 & 0 & 1 \\
\hline Wave 99 & .077 & .261 & 0 & 1 \\
\hline Wave 2000 & .066 & .246 & 0 & 1 \\
\hline Wave 2001 & .10 & .31 & 0 & 1 \\
\hline
\end{tabular}

a. Sample size $=743$ observations on 653 individuals

b. Hourly wage is defined as net monthly income divided by weekly agreed hours times 4.33 .

It does not account for overtime (see Section 3)

c. Changes to jobs with agreed monthly hours below 15 hours or above 50 are excluded. Job changes in which the wage increases by more than 2.71 times, or less than 0.36 times the previous wage are excluded d. Monetary magnitudes in 1995 DM 


\begin{tabular}{|c|c|c|}
\hline & Number of observations & $\begin{array}{l}\text { Mean wage change } \\
\text { (standard deviation) }\end{array}$ \\
\hline Work load worsened & 158 & $\begin{array}{l}.139 \\
(.24)\end{array}$ \\
\hline Work load stayed the same & 316 & $\begin{array}{l}.079 \\
(.22)\end{array}$ \\
\hline Work load improved & 269 & $\begin{array}{c}.056 \\
(.241)\end{array}$ \\
\hline Hours regulation worsened & 120 & $\begin{array}{l}.126 \\
(.25)\end{array}$ \\
\hline Hours regulation stayed the same & 297 & $\begin{array}{l}.061 \\
(.22)\end{array}$ \\
\hline Hours regulation improved & 326 & $\begin{array}{l}.088 \\
(.246)\end{array}$ \\
\hline Job security worsened & 46 & $\begin{array}{l}.13 \\
(.245)\end{array}$ \\
\hline Job security stayed the same & 417 & $\begin{array}{c}.074 \\
(.249)\end{array}$ \\
\hline Job security improved & 280 & $\begin{array}{l}.091 \\
(.22)\end{array}$ \\
\hline Match of skills to knowledge worsened & 117 & $\begin{array}{l}.125 \\
(.256)\end{array}$ \\
\hline Match of skills to knowledge stayed the same & 325 & $\begin{array}{l}.055 \\
(.22)\end{array}$ \\
\hline Match of skills to knowledge improved & 301 & $\begin{array}{c}.099 \\
(.245)\end{array}$ \\
\hline
\end{tabular}

Sample size $=743$ observations on 653 individuals

a. Wage is defined as net monthly income divided by agreed hours, and are not corrected for overtime

b. Changes to jobs with agreed monthly hours below 15 hours or above 56 are excluded. Job changes in which the wage increases by more than 2.71 times, or less than 0.36 times the previous wage are also excluded

c. Monetary magnitudes in 1995 DM 
Table 3: Determinants of the change in the reported "work load" between the old and new job

\begin{tabular}{|c|c|c|c|c|}
\hline \multirow[b]{2}{*}{ Estimation method } & \multicolumn{2}{|c|}{$\begin{array}{l}\text { Dependent variable equals } 1 \\
\text { if work load improves }\end{array}$} & \multicolumn{2}{|c|}{$\begin{array}{l}\text { Dependent variable equals } 1 \\
\text { if work load worsens }\end{array}$} \\
\hline & OLS & Probit & OLS & Probit \\
\hline Reported change in mental stress & $\begin{array}{l}-0.026 \\
(0.038)\end{array}$ & $\begin{array}{l}-0.031 \\
(0.037)\end{array}$ & $\begin{array}{l}-0.004 \\
(0.036)\end{array}$ & $\begin{array}{l}-0.004 \\
(0.040)\end{array}$ \\
\hline Reported change in physical effort & $\begin{array}{c}0.089 \\
(0.044)^{\star *}\end{array}$ & $\begin{array}{c}0.086 \\
(0.043)^{\star *}\end{array}$ & $\begin{array}{c}-0.082 \\
(0.041)^{\star *}\end{array}$ & $\begin{array}{c}-0.099 \\
(0.047)^{\star *}\end{array}$ \\
\hline Reported change in environmental conditions & $\begin{array}{l}-0.016 \\
(0.042)\end{array}$ & $\begin{array}{l}-0.019 \\
(0.041)\end{array}$ & $\begin{array}{l}-0.047 \\
(0.038)\end{array}$ & $\begin{array}{l}-0.065 \\
(0.045)\end{array}$ \\
\hline Reported change in chances of doing shift work & $\begin{array}{c}0.017 \\
(0.047)\end{array}$ & $\begin{array}{c}0.020 \\
(0.046)\end{array}$ & $\begin{array}{l}-0.007 \\
(0.044)\end{array}$ & $\begin{array}{l}-0.004 \\
(0.050)\end{array}$ \\
\hline Change in actual hours of work & $\begin{array}{l}-0.002 \\
(0.002)\end{array}$ & $\begin{array}{l}-0.003 \\
(0.002)\end{array}$ & $\begin{array}{c}0.004 \\
(0.002)^{* *}\end{array}$ & $\begin{array}{c}0.005 \\
(0.002)^{\star *}\end{array}$ \\
\hline$($ Age -30$) / 10$ & $\begin{array}{l}-0.08 \\
(0.05)^{*}\end{array}$ & $\begin{array}{l}-0.08 \\
(0.05)^{*}\end{array}$ & $\begin{array}{c}0.08 \\
(0.04)^{*}\end{array}$ & $\begin{array}{c}0.09 \\
(0.05)^{*}\end{array}$ \\
\hline$(\text { Age }-30)^{*}($ Age -30$) / 100$ & $\begin{array}{c}0.000 \\
(0.000)\end{array}$ & $\begin{array}{c}0.000 \\
(0.000)\end{array}$ & $\begin{array}{l}-0.03 \\
(0.027)\end{array}$ & $\begin{array}{l}-0.06 \\
(0.03)^{*}\end{array}$ \\
\hline Blue collar worker & $\begin{array}{c}0.087 \\
(0.051)^{*}\end{array}$ & $\begin{array}{c}0.091 \\
(0.051)^{*}\end{array}$ & $\begin{array}{c}-0.226 \\
(0.053)^{\star * *}\end{array}$ & $\begin{array}{c}-0.238 \\
(0.055)^{\star * *}\end{array}$ \\
\hline Changed position within the same firm & $\begin{array}{l}-0.033 \\
(0.081)\end{array}$ & $\begin{array}{l}-0.040 \\
(0.086)\end{array}$ & $\begin{array}{c}0.051 \\
(0.102)\end{array}$ & $\begin{array}{c}0.041 \\
(0.104)\end{array}$ \\
\hline Position terminated by employer & $\begin{array}{l}-0.077 \\
(0.068)\end{array}$ & $\begin{array}{l}-0.073 \\
(0.058)\end{array}$ & $\begin{array}{c}0.056 \\
(0.063)\end{array}$ & $\begin{array}{c}0.073 \\
(0.082)\end{array}$ \\
\hline Constant & $\begin{array}{c}0.274 \\
(0.042)^{* * *} \\
\end{array}$ & & $\begin{array}{c}0.392 \\
(0.045)^{* * *} \\
\end{array}$ & \\
\hline $\begin{array}{l}\text { Number of observations: } \\
\text { R-squared }\end{array}$ & $\begin{array}{l}360 \\
0.06\end{array}$ & 360 & $\begin{array}{l}360 \\
0.17\end{array}$ & 360 \\
\hline
\end{tabular}

R-squared

b. Change in mental stress takes value 1 if the new job requires less mental stress,

0 if it requires the same mental stress and -1 if the new job requires less mental stress.

c. Changes in physical effort takes value 1(-1) if the new job requires less (more) physical effort than the previous one, 0 if the same.

d. Changes in environmental conditions takes value 1(-1) if the new job has better (worse) conditions than the previous one, 0 if the same.

e. Changes in chances of doing shift work takes value $1(-1)$ if the new job has less (more) chances of requiring shift work than the

previous one, 0 if the same.

f. Change in actual hours of work is the difference in actual hours of work in a regular week between new and old job

g. Estimates of the derivative of the probability of report with respect to characteristics using PROBIT models 
Table 4: Determinants of the change in the reported "hours regulation" between the old and new job -all separations

\begin{tabular}{|c|c|c|c|c|}
\hline & \multicolumn{2}{|c|}{$\begin{array}{l}\text { Dependent variable takes value } 1 \\
\text { if hours regulation improves }\end{array}$} & \multicolumn{2}{|c|}{$\begin{array}{l}\text { Dependent variable takes value } 1 \\
\text { if hours regulation worsens }\end{array}$} \\
\hline & OLS & PROBIT & OLS & PROBIT \\
\hline \multirow[t]{2}{*}{ Change in mental stress } & -0.045 & -0.047 & -0.013 & -0.013 \\
\hline & $(0.038)$ & $(0.040)$ & $(0.032)$ & $(0.032)$ \\
\hline \multirow[t]{2}{*}{ Change in physical effort } & 0.024 & 0.024 & -0.048 & -0.065 \\
\hline & $(0.040)$ & $(0.041)$ & $(0.036)$ & $(0.036)^{*}$ \\
\hline \multirow[t]{2}{*}{ Change in environmental conditions } & 0.067 & 0.065 & -0.044 & -0.047 \\
\hline & $(0.043)$ & $(0.043)$ & $(0.032)$ & $(0.034)$ \\
\hline \multirow[t]{2}{*}{ Change in chances of working night shift } & -0.004 & -0.003 & -0.016 & -0.020 \\
\hline & $(0.047)$ & $(0.049)$ & $(0.039)$ & $(0.041)$ \\
\hline \multirow[t]{2}{*}{ Changes in hours } & -0.005 & -0.005 & 0.006 & 0.005 \\
\hline & $(0.002)^{* * *}$ & $(0.002)^{\star * \star}$ & $(0.001)^{* * *}$ & $(0.001)^{* * *}$ \\
\hline \multirow[t]{2}{*}{ Changes in overtime hours } & -0.009 & -0.013 & 0.011 & 0.009 \\
\hline & $(0.006)$ & $(0.0077)$ & $(0.006)^{*}$ & $(0.005)^{*}$ \\
\hline \multirow[t]{2}{*}{$($ Age - 30)/10 } & -0.04 & -0.05 & 0.06 & 0.06 \\
\hline & $(0.05)$ & $(0.05)$ & $(0.04)$ & $(0.04)$ \\
\hline \multirow[t]{2}{*}{$(\text { Age }-30)^{*}($ Age -30$) / 100$} & -0.000 & 0.000 & -0.05 & -0.05 \\
\hline & $(0.03)$ & $(0.03)$ & $(0.021)^{\star *}$ & $(0.026)^{* *}$ \\
\hline \multirow{2}{*}{ Blue collar } & 0.071 & 0.077 & -0.153 & -0.158 \\
\hline & $(0.052)$ & $(0.052)$ & $(0.045)^{\star * *}$ & $(0.046)^{* * *}$ \\
\hline \multirow[t]{2}{*}{ Job change within the firm } & -0.007 & -0.032 & -0.231 & -0.183 \\
\hline & $(0.084)$ & $(0.096)$ & $(0.079)^{\star * *}$ & $(0.051)^{* * *}$ \\
\hline \multirow[t]{2}{*}{ Involuntary job change } & -0.071 & -0.068 & 0.050 & 0.053 \\
\hline & $(0.073)$ & $(0.063)$ & $(0.056)$ & $(0.067)$ \\
\hline \multirow[t]{2}{*}{ Constant } & 0.358 & & 0.299 & \\
\hline & $(0.045)^{* * *}$ & & $(0.039)^{\star * *}$ & \\
\hline Number of observations & 359 & 359 & 359 & 359 \\
\hline R-squared & 0.12 & & 0.13 & \\
\hline
\end{tabular}

a. Standard errors are corrected for heteroskedasticity. ${ }^{* * *}$ and ${ }^{* * *}$ denotes statistical significance at the 10,5 and $1 \%$ confidence level.

within observations from the same individual

b. Change in mental stress takes value 1 if the new job requires less mental stress,

0 if it requires the same mental stress and -1 if the new job requires less mental stress.

c. Changes in physical effort takes value $1(-1)$ if the new job requires less (more) physical effort than the previous one, 0 if the same.

d. Changes in environmental conditions takes value 1(-1) if the new job has better (worse) conditions than the previous one, 0 if the same.

e. Changes in chances of doing shift work takes value 1(-1) if the new job has less (more) chances of requiring shift work than the

f. Change in actual hours of work takes value 1(-1) if the job requires less (more) hours than the previous, 0 otherwise

g. Changes in overtime is the difference between the number in overtime hours in the previous month in the current job

and the previous one.

h. The estimates in the PROBIT column reflect the derivative of the probability with respect to the characteristic,

evaluated at sample means 
Table 5: The effect of changes in job characteristics on self-reported satisfaction -sample of quits

Dependent variable: change in reported satisfaction after a job change, scale from -10 to 10

Estimation method: Ordered Logit

\begin{tabular}{|c|c|c|c|c|c|}
\hline & [Model I] & [Model II] & [Model III] & [Model IV] & [Model V] \\
\hline Change in earnings & 0.147 & 0.356 & 0.364 & 0.355 & 0.404 \\
\hline ( 1 if improved, zero if same, -1 if worse) & $(0.082)^{*}$ & $(0.086)^{\star * *}$ & $(0.090)^{\star \star *}$ & $(0.090)^{* * *}$ & $(0.070)^{\star * *}$ \\
\hline Change in security on the job & $\begin{array}{c}0.230 \\
(0.103)^{\star *}\end{array}$ & $\begin{array}{c}0.378 \\
(0.111)^{\star * *}\end{array}$ & $\begin{array}{c}0.437 \\
(0.114)^{\star * *}\end{array}$ & $\begin{array}{c}0.446 \\
(0.116)^{\star * *}\end{array}$ & $\begin{array}{c}0.488 \\
(0.095)^{\star * *}\end{array}$ \\
\hline Change in work load & $\begin{array}{c}0.239 \\
(0.080)^{\star * *}\end{array}$ & $\begin{array}{c}0.383 \\
(0.085)^{\star * *}\end{array}$ & $\begin{array}{c}0.404 \\
(0.088)^{* * *}\end{array}$ & $\begin{array}{c}0.432 \\
(0.090)^{\star * *}\end{array}$ & $\begin{array}{c}0.424 \\
(0.076)^{* * *}\end{array}$ \\
\hline Change in hours regulation & $\begin{array}{c}0.140 \\
(0.087)\end{array}$ & $\begin{array}{c}0.157 \\
(0.090)^{*}\end{array}$ & $\begin{array}{c}0.180 \\
(0.093)^{*}\end{array}$ & $\begin{array}{c}0.168 \\
(0.095)^{*}\end{array}$ & $\begin{array}{c}0.172 \\
(0.080)^{\star *}\end{array}$ \\
\hline Change in fringe benefits & $\begin{array}{c}0.044 \\
(0.101)\end{array}$ & $\begin{array}{c}0.019 \\
(0.102)\end{array}$ & $\begin{array}{c}0.031 \\
(0.105)\end{array}$ & $\begin{array}{c}0.026 \\
(0.106)\end{array}$ & $\begin{array}{c}0.073 \\
(0.088)\end{array}$ \\
\hline Change in commuting & $\begin{array}{l}-0.002 \\
(0.070)\end{array}$ & $\begin{array}{l}0.076 \\
(0.068)\end{array}$ & $\begin{array}{c}0.051 \\
(0.071)\end{array}$ & $\begin{array}{c}0.054 \\
(0.071)\end{array}$ & $\begin{array}{c}0.039 \\
(0.063)\end{array}$ \\
\hline Change in use of skills & $\begin{array}{c}0.452 \\
(0.085)^{\star * *}\end{array}$ & $\begin{array}{c}0.562 \\
(0.089)^{\star * *}\end{array}$ & $\begin{array}{c}0.567 \\
(0.091)^{* * *}\end{array}$ & $\begin{array}{c}0.553 \\
(0.091)^{\star * *}\end{array}$ & $\begin{array}{c}0.516 \\
(0.080)^{* * *}\end{array}$ \\
\hline $\begin{array}{l}\text { Satisfaction before the change } \\
\text { (from } 0 \text {, very unsatisfied, to } 10 \text {, very satisf }\end{array}$ & & $\begin{array}{c}-0.948 \\
(0.038)^{\star \star *}\end{array}$ & $\begin{array}{c}-0.962 \\
(0.038)^{\star \star \star}\end{array}$ & $\begin{array}{c}-0.963 \\
(0.038)^{\star * *}\end{array}$ & $\begin{array}{c}-0.889 \\
(0.033)^{\star * *}\end{array}$ \\
\hline Age -30 & & & & $\begin{array}{l}-0.009 \\
(0.014)\end{array}$ & $\begin{array}{l}-0.009 \\
(0.011)\end{array}$ \\
\hline Age - 30 squared & & & & $\begin{array}{l}-0.000 \\
(0.001)\end{array}$ & $\begin{array}{l}-0.000 \\
(0.001)\end{array}$ \\
\hline Not married & & & & $\begin{array}{c}0.052 \\
(0.135)\end{array}$ & $\begin{array}{c}0.022 \\
(0.116)\end{array}$ \\
\hline college & & & & $\begin{array}{c}0.369 \\
(0.307)\end{array}$ & $\begin{array}{c}0.213 \\
(0.255)\end{array}$ \\
\hline novocation & & & & $\begin{array}{l}-0.114 \\
(0.190)\end{array}$ & $\begin{array}{c}0.071 \\
(0.163)\end{array}$ \\
\hline missed & & & & $\begin{array}{l}-0.076 \\
(0.306)\end{array}$ & $\begin{array}{l}-0.197 \\
(0.254)\end{array}$ \\
\hline Years of education & & & & $\begin{array}{l}-0.008 \\
(0.046)\end{array}$ & $\begin{array}{c}0.030 \\
(0.039)\end{array}$ \\
\hline Wave dummies & Y & Y & Y & Y & Y \\
\hline Industry dummies & No & No & Yes & Yes & Yes \\
\hline Sample size & 1,164 & 1,164 & 1,164 & 1,164 & 1,151 \\
\hline
\end{tabular}

${ }^{*},{ }^{* *}$ and ${ }^{* * *}$ : the estimate is significantly different from zero at the 10, 5 and 1 percent confidence level, resp.

a. Coefficients are the ordered logit coefficients.

b. Standard errors are corrected for heteroscedasticity and arbitrary autocorrelation within individuals.

c. Work load takes value $1(-1)$ if the new job has a better(worse) work load than the previous one, zero if similar.

d. Earnings takes value 1(-1) if earnings in new job are higher than in the previous one, zero if similar

e. Fringe benefits takes value $1(-1)$ if the new job has better benefits than the previous one, zero if similar

f. Commuting takes value 1(-1) if the new job implies a shorter (longer) commute than the previous one, zero if similar g. Use of skills takes value $1(-1)$ if new job the worker uses more(less) his skills in the present job than

in the previous one, zero if the use is similar. 
Table 6: The effect of nonpecuniary characteristics on hourly wages.

Dependent variable: Change in the logarithm of the contracted hourly wage after a quit Independent vars. Sign Model I Model II Model III Model IV consistent with CD

Work load worsened

(1 if worsened, 0 otherwise)

Work load improved

(1 if improved, 0 ow.)

Hours regulation worsened

(1 if worsened, 0 ow.)

Hours regulation improved

(1 if improved, 0 ow.)

Use less knowledge

(1 if worsened, 0 ow.)

Use more knowledge

(1 if improved, 0 ow.)

Job security worsened

(1 if worsened, 0 ow.)

Job security improved

(1 if improved, 0 ow.)

(Age - 30)/10

$(\text { Age }-30)^{\star}($ Age -30$) / 100$

Satisfaction with job prior to the change

Satisfaction with health prior to change

Not married

Destination firm had more 2000 employees

Previous firm had more 2000 employees

Years of Education

Constant

Industry dummies

Wave dummies

Other job characteristics

Number of observations

R-squared

positive

positive

positive

positive
zero/negative

zero/negative

zero/negative

zero/negative 
Table 7: The effect of nonpecuniary characteristics on hourly wages

Dependent variable: Change in the logarithm of the contracted hourly wage after a quit Independent vars. Sign Model I Model II Model III Model V consistent with $\mathrm{CD}$

Work load worsened

$\begin{array}{lllll}\text { positive } & 0.044 & 0.040 & 0.042 & 0.045\end{array}$

(1 if worsened, 0 ow.) Work load improved (1 if improved, 0 ow.) Hours regulation worsened (1 if worsened, 0 ow.) Hours regulation improved (1 if improved, 0 ow.) Use less knowledge (1 if worsened, 0 ow.) Use more knowledge (1 if improved, 0 ow.) Job security worsened (1 if worsened, 0 ow.) Job security improved (1 if improved, 0 ow.) $\begin{array}{llll}(0.024)^{*} & (0.025) & (0.025)^{*} & (0.025)^{*}\end{array}$ zero/negative $\quad-0.046 \quad-0.042 \quad-0.035 \quad-0.035$ $\begin{array}{ccccc}(0.020)^{* *} & (0.020)^{* *} & (0.020)^{*} & (0.020)^{*}\end{array}$ $\begin{array}{lllll}\text { positive } & 0.044 & 0.045 & 0.043 & 0.043\end{array}$ $\begin{array}{llll}(0.027) \quad(0.027)^{*} & (0.027) \quad(0.027)\end{array}$

zero/negative $\quad \begin{array}{lllll}0.035 & 0.034 & 0.033 & 0.035\end{array}$

$\begin{array}{ccccc}\text { zero/negative } & 0.035 & 0.034 & 0.033 & 0.035 \\ & (0.020)^{*} & (0.020)^{*} & (0.020) & (0.021)^{*}\end{array}$ $\begin{array}{lllll}\text { positive } & 0.065 & 0.066 & 0.075 & 0.074\end{array}$ Increase in overtime/agreed hours

\begin{tabular}{|c|c|c|c|c|}
\hline & $(0.026)^{\star *}$ & $(0.026)^{* *}$ & $(0.026)^{\star \star *}$ & $(0.027)^{\star \star \star}$ \\
\hline \multirow[t]{2}{*}{ zero/negative } & 0.029 & 0.026 & 0.021 & 0.020 \\
\hline & $(0.019)$ & $(0.019)$ & $(0.020)$ & $(0.020)$ \\
\hline \multirow[t]{2}{*}{ positive } & 0.010 & 0.010 & 0.042 & 0.039 \\
\hline & $(0.040)$ & $(0.041)$ & $(0.041)$ & $(0.041)$ \\
\hline \multirow[t]{2}{*}{ zero/negative } & 0.015 & 0.016 & -0.006 & -0.009 \\
\hline & $(0.018)$ & $(0.018)$ & $(0.019)$ & $(0.019)$ \\
\hline & 0.217 & 0.206 & 0.223 & 0.226 \\
\hline & $(0.075)^{\star \star \star}$ & $(0.075)^{\star * \star}$ & $(0.074)^{\star \star *}$ & $(0.074)^{* * *}$ \\
\hline & $\begin{array}{c}0.069 \\
(0.038)^{*}\end{array}$ & $\begin{array}{c}0.062 \\
(0.037)^{*}\end{array}$ & $\begin{array}{c}0.067 \\
(0.064)\end{array}$ & $\begin{array}{c}0.053 \\
(0.067)\end{array}$ \\
\hline
\end{tabular}

Constant

$\begin{array}{llll}\mathrm{N} & \mathrm{N} & \mathrm{Y} & \mathrm{Y}\end{array}$

Industry dummies?

Wave Dummies?

Other characteristics of jobs

Sample size

$\mathrm{Y} \quad \mathrm{Y}$

R squared

$\mathrm{N} \quad \mathrm{N}$

\footnotetext{
a. Wages are defined as the ratio of income last month divided by the number of hours agreed.

b. All specifications contain the same regressors as the corresponding models in Table 6, omitted for brevity

c. Standard errors are corrected for heterogeneity in rates of growth across individuals

d. The reference group consists of individuals who changed jobs in 1990, nonpecuniary characteristics were reported to be the same in the new and in the previous job, and had completed vocational education.
} 
Table 8: The effect of nonpecuniary characteristics on hourly wages, within-firm changers

Dependent variable: Change in logarithm of contracted hourly wage after a change within the firm Variable Model VI Model VII

Model VIII

Model IX

Mean

Work load worsened

(1 if worsened, 0 ow.)

0.007

$(0.022)$

0.003

(0.022)

0.011

(0.023)

0.015

(st. dev.)

Work load improved

(1 if improved, 0 ow.)

$-0.025$

$-0.024$

$-0.021$

(0.023)

(.49)

Hours regulation worsened

(0.025)

(0.025)

(0.028)

$-0.018$

.19

0.005

0.006

(0.025)

(0.025)

0.008

(0.028)

(0.027)

0.006

(0.028)

$-0.053$

$-0.052$

$-0.042$

$-0.053$

.18

Hours regulation improved

(1 if improved, 0 ow.)

$(0.028)^{*}$

$(0.029)^{*}$

(0.031)

$(0.031)^{*}$

(.38)

Use less knowledge

(1 if worsened, 0 ow.)

$-0.067$

$-0.064$

$-0.063$

$-0.038$

$(0.029)^{* *}$

$(0.031)^{\star *}$

$(0.034)^{*}$

(0.036)

.16

$-0.002$

$-0.003$

$-0.003$

$-0.014$

(0.021)

(0.021)

(0.020)

(0.020)

0.048

0.070

(0.053)

(0.050)

(0.058)

$(0.058)$

0.032

(0.025)

0.036

(0.025)

0.019

0.007

(0.026)

(0.029)

(.37)

$-0.045$

$-0.053$

(0.033)

(0.033)

$-0.059$

$-0.063$

$(0.034)^{*}$

$(0.033)^{\star}$

.14

(.35)

$(\text { Age }-30)^{\star}($ Age -30$) / 100$

0.014

0.017

(0.016)

(0.016)

0.017

0.020

$-0.003$

$-0.003$

(0.017)

(0.017)

Satisfaction with job prior to change

(0.006)

(0.006)

$-0.002$

0.000

$-.10$

(0.006)

(0.006)

(1.48)

Education missing

0.027

0.032

0.031

.05

(0.065)

(0.068)

(0.069)

(.22)

Years of Education

0.005

0.005

0.006

12.52

(0.006)

(0.006)

(0.007)

(2.59)

Satisfaction with health prior to change

0.002

0.001

$-0.001$

7.31

(0.004)

(0.005)

(0.005)

(2.00)

Not married

$-0.023$

$-0.027$

$-0.026$

$-0.032$

.32

(0.025)

(0.025)

(0.026)

(0.026)

0.132

0.135

$-0.200$

$-0.201$

(.47)

Constant

$(0.040)^{* * *}$

$(0.039)^{* * *}$

$(0.057)^{* * *}$

$(0.059)^{\star * *}$

Industry dummies

Wave dummies

Other job characteristics

Number of observations

$$
\mathrm{N}
$$

$\mathrm{N}$

$\mathrm{Y} \quad \mathrm{Y}$

$\begin{array}{cc}\mathrm{N} & \mathrm{N} \\ 316 & 316\end{array}$

Y

Y

0.15

0.16

a. The sample consists of 274 individuals, for whom we observe 316 changes whithin the firm

b. Wages are defined as the ratio of income last month divided by agreed hours.

c. Standard errors are corrected for heterogeneity in individual wage growth rates, and for correlation between observations

d. The reference group consists of individuals who changed jobs in 1990, nonpecuniary characteristics

were reported to be the same in the new and in the previous job, and had completed vocational education. 
Table A.1 Descriptive statistics of the sample used for the regressions in Tables 3 and 4

\begin{tabular}{lcccc}
\hline \multicolumn{1}{c}{ Variable } & Mean & Std. Deviation & Minimum & Maximum \\
\hline Work load improved & .28 & .45 & 0 & 1 \\
Work load worsened & .319 & .466 & 0 & 1 \\
Hours regulation improved & .306 & .461 & 0 & 1 \\
Hours regulation worsened & .194 & .396 & 0 & 1 \\
Reported change in mental stress & .056 & .67 & -1 & 1 \\
Reported change in physical effort & .194 & .588 & -1 & 1 \\
Reported change in environmental conditions & .123 & .607 & -1 & 1 \\
Reported change in chances of doing shift work & -.029 & .526 & -1 & 1 \\
Change in actual hours of work & .171 & .639 & -1 & 1 \\
Change in hours of (monthly hours of) overtime & .33 & .43 & -12 & 16.8 \\
Age & 34.08 & 8.7 & 20 & 60 \\
Blue collar worker & .49 & .5 & 0 & 1 \\
Changed position within the same firm & .27 & .44 & 0 & 1 \\
Position terminated by employer & .17 & .38 & 0 & 1 \\
\hline Sample size: & & & 360 & \\
\hline Change in & & & \\
\hline
\end{tabular}

a. Change in mental stress takes value 1 if the new job requires less mental stress,

0 if it requires the same mental stress and -1 if the new job requires less mental stress.

b. Changes in physical effort takes value 1(-1) if the new job requires less (more) physical effort than the previous one, 0 if the same.

c. Changes in environmental conditions takes value 1(-1) if the new job has better (worse) conditions than the previous one, 0 if the same.

d. Changes in chances of doing shift work takes value $1(-1)$ if the new job has less (more) chances of requiring shift work than the previous one, 0 if the same.

e. Change in actual hours of work takes value $1(-1)$ if the job requires less (more) hours than the previous, 0 otherwise 